\author{
DOMINIKA UCZKIEWICZ \\ ORCID: 0000-0002-9455-659X \\ Uniwersytet Wrocławski
}

Centrum Studiów Niemieckich i Europejskich im. W. Brandta

\title{
Dekret Prezydenta Rzeczypospolitej Polskiej o odpowiedzialności karnej za zbrodnie wojenne z dnia 30 marca 1943 roku* $^{*}$
}

„Rząd domagać się będzie [...] surowego ukarania winnych obecnej wojny, Niemiec i ich sojuszników. Za wyrządzone przez siebie krzywdy, za dokonane zbrodnie i zniszczenia ponieść oni muszą zasłużoną karę, dając równocześnie poszkodowanym całkowite zadośćuczynienie materialne i moralne. Jest to nakaz elementarnej sprawiedliwości dziejowej, która panować musi w stosunkach międzynarodowych" - tymi słowami minister sprawiedliwości rządu polskiego na emigracji, prof. Wacław Komarnicki, rozpoczął swoje wystąpienie w trakcie posiedzenia Rady Ministrów w dniu 2 lipca 1942 roku, przedstawiając opracowany wspólnie z prof. Stefanem Glaserem projekt Dekretu Prezydenta Rzeczypospolitej Polskiej o odpowiedzialności karnej za niektóre zbrodnie popełnione w czasie wojny (tak brzmiał roboczy tytuł dekretu). Profesor Komarnicki użył tu cytatu z deklaracji zasad programowych rządu polskiego na emigracji, ogłoszonych podczas otwarcia prac II Rady Narodowej, 24 lutego 1942 roku (deklaracja lutowa) ${ }^{2}$.

* Przedstawione w artykule wyniki badań stanowią fragment przygotowywanej przez autorkę monografii poświęconej problemowi represji karnej nazistowskich zbrodniarzy wojennych w pracach Rządu RP na emigracji.

${ }^{1}$ Referat Ministra Sprawiedliwości o projekcie dekretu o karaniu za zbrodnie wojenne, wygłoszony na posiedzeniu Rady Ministrów w dniu 2 lipca 1942 roku, Instytut Polski i Muzeum im. gen. Sikorskiego w Londynie (dalej: IPMS), PRM-K.102/48a, k. 9-11, przedruk w: Protokoły posiedzeń Rady Ministrów Rzeczypospolitej Polskiej, red. M. Zagórniak, t. 4, Kraków 1998, s. 355-359 (dalej: Protokoty...).

2 Zob. Deklaracja Rządu Jedności Narodowej (deklaracja lutowa) z 24 lutego 1942 roku, Dz.U. RP z 1943 r. Nr 8. Zob. także: A. Jankiewicz, W poszukiwaniu idei państwa prawa. Koncepcje Komisji Prac Ustawodawczych Rządu RP (1942-45), Warszawa 1992, s. 58-65. 
Włączając postulat ukarania niemieckich zbrodniarzy wojennych do oficjalnego programu politycznego, jakim była deklaracja lutowa, gabinet Władysława Sikorskiego uczynił zdecydowany krok w kierunku realizacji ogłoszonych już pod koniec 1939 roku planów postawienia przed sądem winnych popełnienia zbrodni w trakcie działań wojennych lub okupacji ${ }^{3}$. Kolejnym, jeszcze bardziej stanowczym posunięciem było rozpoczęcie w kwietniu 1942 roku prac legislacyjnych, w wyniku których 31 marca 1943 roku w Dzienniku Ustaw ogłoszony został Dekret Prezydenta Rzeczypospolitej Polskiej o odpowiedzialności karnej za zbrodnie wojenne ${ }^{4}$. W niniejszym artykule przedstawione zostaną geneza i założenia dekretu oraz dyskusje, jakie towarzyszyły pracom nad treścią tego aktu prawnego.

\section{Geneza}

Problem represji karnej zbrodniarzy wojennych od pierwszych tygodni wojny należał do priorytetów polityki wewnętrznej i zagranicznej Rządu Rzeczypospolitej Polskiej na emigracji ${ }^{5}$. Już jesienią 1939 roku władze polskie rozpoczęły akcję dyplomatyczną, której celem było informowanie opinii światowej o zbrodniach dokonywanych na ziemiach polskich - a z czasem i w innych krajach okupowanych — oraz zdobycie poparcia aliantów dla postulatu pociągnięcia sprawców naruszeń praw i zwyczajów prowadzenia wojny do indywidualnej odpowiedzialności karnej. Działania te obejmowały zbieranie i zabezpieczanie materiału dowodowego na potrzeby przyszłych procesów karnych ${ }^{6}$, publikowa-

${ }^{3}$ Zapowiedź ukarania winnych popełnienia zbrodni wojennych została sformułowana w jednej z pierwszych uchwał Rady Ministrów rządu polskiego na emigracji z 15 grudnia 1939 roku: „Wobec potwornych, masowych egzekucji patriotów polskich, dokonanych i dokonywanych w dalszym ciągu z polecenia władz niemieckich w Polsce, a w szczególności na jej bezprawnie do Rzeszy wcielonych ziemiach zachodnich, Rząd polski uważa za swój obowiązek złożyć następujące oświadczenie: Po zwycięskiej wojnie Państwo Polskie zastosuje za niewinne ofiary polskie retorsje wobec Niemiec, i to zwłaszcza wobec ich sfer kierowniczych" - cyt. za: M. Kwiatkowski, Rzad i Rada Narodowa RP w świetle faktów i dokumentów od września 1939 do lutego 1942, Londyn 1942, s. 25.

4 Dekret Prezydenta Rzeczypospolitej Polskiej o odpowiedzialności karnej za zbrodnie wojenne z dnia 30 marca 1943 roku, Dz.U. RP z 1943 r. Nr 3, poz. 6.

5 Zob. F. Ryszka, U progu Norymbergi. Ściganie zbrodni wojennych w projektach polskich władz emigracyjnych, „Czasopismo Prawno-Historyczne” 30, 1978, nr 2, s. 155-186. Proces kształtowania się polityki polskich władz emigracyjnych wobec kwestii ścigania i karania zbrodniarzy wojennych i jej najważniejsze elementy omawia D. Uczkiewicz, Verfolgung außerhalb der Heimat. Die Politik der polnischen Exilregierung bei der strafrechtlichen Verfolgung von NS-Kriegsverbrechen, [w:] Im Schatten von Nürnberg. Transnationale Ahndung von NS-Verbrechen, red. E. Heitzer, G. Morsch, R. Traba, K. Woniak, Berlin 2019, s. 223-242.

${ }^{6}$ Pierwsze szczegółowe instrukcje dla członków polskiej konspiracji w zakresie dokumentacji zbrodni okupantów zostały sporządzone przez Komitet Ministrów dla Spraw Kraju w listopadzie i grudniu 1939 roku, wtedy też przy Prezydium Rady Ministrów utworzono Dział Rejestracji Krzywd i Zbrodni Okupanta. Zob. Protokół posiedzenia Komitetu Ministrów dla Spraw Kraju 
nie relacji i raportów z okupowanej Polski oraz opracowywanie białych ksiąg ${ }^{7}$, a także akcje protestacyjne oraz deklaracje państw alianckich potępiających niemieckie okrucieństwa. Od stycznia 1940 roku ambasador RP w Wielkiej Brytanii Edward Raczyński i minister spraw zagranicznych August Zaleski prowadzili w Londynie i Paryżu negocjacje w sprawie treści wspólnej deklaracji premierów Wielkiej Brytanii, Francji i Polski, piętnującej zbrodnie dokonywane przez policyjny, wojskowy i administracyjny aparat Rzeszy Niemieckiej. Zasadnicze postulaty strony polskiej dotyczyły umieszczenia w treści rezolucji zapowiedzi dochodzenia pełnego odszkodowania poniesionych przez Polskę start oraz pociągnięcia zbrodniarzy wojennych do osobistej odpowiedzialności karnej ${ }^{8}$. Wobec braku zgody ze strony Foreign Office na wiążącą zapowiedź przeprowadzenia procesów karnych zbrodniarzy wojennych tekst ogłoszonej 20 kwietnia 1940 roku deklaracji wyrażał sprzeciw wobec polityki niemieckiej „zmierzającej świadomie do zniszczenia narodu polskiego" i prześladowań ludności żydowskiej oraz zawierał stwierdzenie, że rządy państw-sygnatariuszy uznają „odpowiedzialność Niemiec za te zbrodnie i są zdecydowane zapewnić odszkodowanie krzywd [...] wyrządzonych ludności Polski"9. Brak przekonania rządu brytyjskiego o potrzebie doprecyzowywania zasad „odpowiedzialności Niemiec za zbrodnie” okazał się stałym elementem brytyjskiej war crimes policy ${ }^{10}$, a jednocześnie istotnym czynnikiem warunkującym starania gabinetu Władysława Sikorskiego o rozpoczęcie na forum międzynarodowym prac nad określeniem podstaw prawnych karania zbrodniarzy wojennych.

z 12 grudnia 1939 roku, [w:] Protokoły posiedzeń Komitetu Ministrów dla Spraw Kraju. Część 1: 1939-1941, oprac. W. Grabowski, Warszawa 2008, s. 88.

7 Polish Ministry of Information, The persecution of Jews in German-occupied Poland, Chicago 1940; Polish Information Centre, Documents Relating to the Administration of Occupied Countries in Eastern Europe, New York 1941; Polish Ministry of Information, The German New Order in Poland, London 1942; M. Lachs, The Ghetto of Warsaw, London1942; Rząd Rzeczypospolitej Polskiej na Uchodźstwie. Ministerstwo Spraw Zagranicznych, The Polish White Book. Official Documents concerning Polish-German and Polish-Soviet Relations 1933-1939, London1940; Ministerstwo Spraw Zagranicznych, L'Occupation Allemande et Sovietique de la Pologne, 1941.

8 Protokoły posiedzeń Rady Ministrów z 1 i 13 lutego oraz 16 marca 1940 roku, The National Archives (TNA), TNA/FO 371.24422.

9 Przedruk tekstu Deklaracji rządów Polski, Wielkiej Brytanii i Francji potępiającej metody okupanta niemieckiego w: Sprawa polska w czasie drugiej wojny światowej na arenie międzynarodowej. Zbiór dokumentów, oprac. S. Stanisławska, Warszawa 1965, dok. nr 95, s. 162. Fragmenty deklaracji cytuje i okoliczności jej powstania omawia A.J. Kochavi, Prelude to Nuremberg: Allied War Crimes Policy and the Question of Punishment of War Criminals, Chapel Hill-London 1988, s. 7-9.

10 Problem pasywnego stanowiska rządu brytyjskiego wobec kwestii ścigania i karania zbrodniarzy wojennych w kontekście prac Komisji Narodów Zjednoczonych do spraw Zbrodni Wojennych, a więc od jesieni 1943 roku omawia A.J. Kochavi, The British Foreign Office versus the United Nations War Crimes Commission during the Second World War, „Holocaust \& Genocide Studies" 28, 1994, s. 28-49, tu: s. 30. 


\section{W cieniu ,farsy lipskiej”}

Fiasko podjętej po I wojnie światowej próby osądzenia „winnych naruszeń praw i zwyczajów wojennych" (art. 228-230 traktatu wersalskiego) oraz pociągnięcia do odpowiedzialności karnej Wilhelma II Hohenzollerna oskarżonego o „najwyższą obrazę moralności międzynarodowej i świętej powagi traktatów” (art. 227 traktatu wersalskiego) ${ }^{11}$ traktowane było jako argument przez zarówno przeciwników, jak i zwolenników ustalania ram materialnych i procesowych przyszłych procesów zbrodniarzy wojennych w latach II wojny światowej. Wyrażony w pierwszych miesiącach 1940 roku sceptycyzm Brytyjczyków co do skuteczności ewentualnych procesów karnych przestępców wojennych tłumaczono niepowodzeniem wdrożenia w roku 1919 przewidzianej w art. 228 traktatu wersalskiego procedury ekstradycyjnej i „farsą”, jaką okazały się procesy karne przed Sądem Najwyższym Rzeszy w Lipsku ${ }^{12}$ przeciwko czterdziestu pięciu spośród niemal dziewięciuset oskarżonych przez państwa ententy o złamanie praw i zwyczajów prowadzenia wojny, w których zapadło łącznie dwanaście wyroków skazujących. Jak negocjacje tekstu polsko-francusko-brytyjskiej deklaracji na przełomie lutego i marca 1940 roku relacjonował August Zaleski, „Anglicy nie chcą się zgodzić na ustęp przewidujący sankcję, tłumacząc się tym, że Niemcy mogą wykpić groźby sankcyjne, wskazując na niewykorzystanie sankcji przewidzianych Traktatem Wersalskim"13. Długotrwałość ewentualnych procesów zbrodniarzy wojennych oraz trudności natury technicznej, związane z organizacją międzynarodowego wymiaru sprawiedliwości, brak sankcji karnych za łamanie przepisów konwencji haskiej z 1907 roku, dotyczącej praw i zwyczajów wojny lądowej i zasad jurysdykcji międzynarodowej w przypadkach naruszeń postanowień konwencji czy innych umów międzynarodowych ograniczających metody prowadzenia wojny, uważano za dodatkowe argumenty przeciw określaniu zasad pociągania do odpowiedzialności karnej za zbrodnie wojenne popełnione po 1 września 1939 roku $^{14}$. Przez prawników polskich nieudana próba osądzenia

11 Traktat pokoju między mocarstwami sprzymierzonemi i skojarzonemi i Niemcami, podpisany w Wersalu dnia 28 czerwca 1919 roku, Dz.U. z 1920 r. Nr 35, poz. 200.

12 J. Willis, Prologue to Nuremberg: The Politics and Diplomacy of Punishing War Criminals of the First World War, Westport 1982, s. 8-12; G. Hankel, Die Leipziger Prozesse. Deutsche Kriegsverbrechen und ihre strafrechtliche Verfolgung nach dem Ersten Weltkrieg, Hamburg 2003.

13 Protokół posiedzenia Rady Ministrów z 1 marca 1940 roku, IPMS, PRM-K. 102/18, przedruk w: Protokoty..., t. 1, s. 216.

14 A.J. Kochavi, Prelude to..., s. 14-21. Rezerwa ta nie dotyczyła jedynie postulatów zgłaszanych przez rząd polski w pierwszych miesiącach wojny czy późniejszych wspólnych wystąpień europejskich rządów emigracyjnych. Poparcia ze strony Foreign Office i rządu amerykańskiego nie uzyskał także projekt utworzenia międzynarodowego trybunału karnego do sądzenia zbrodniarzy wojennych (United Nations War Crimes Court), przedstawiony w październiku 1944 przez Komisję Narodów Zjednoczonych do spraw Zbrodni Wojennych (United Nations War Crimes Commission). Pierwsze decyzje dotyczące organizacji wymiaru sprawiedliwości dla zbrodniarzy wojennych rządy Stanów Zjednoczonych i Wielkiej Brytanii podjęły dopiero w 1945 roku. W ich wyniku 8 sierpnia 
przestępców wojennych po I wojnie światowej i wykonania art. 227-230 traktatu wersalskiego traktowana była raczej jako przestroga i „czarny scenariusz”, do którego ziszczenia nie można było dopuścić. W ogłoszonym 21 kwietnia 1940 roku Projekcie instrukcji Komitetu dla Spraw Kraju w sprawie dokumentacji w Polsce działalności okupantów ${ }^{15}$, zawierającym wytyczne rządowe dotyczące sporządzania dokumentacji aktów naruszeń praw i zwyczajów prowadzenia wojny, bezpośrednio odniesiono się do doświadczenia belgijskiego z I wojny światowej — ze względu na brak szczegółowej dokumentacji zbrodni niemieckich w wielu wypadkach niemożliwe było zidentyfikowanie sprawców i postawienie ich przed sądem. Dlatego w Instrukcji z kwietnia 1940 roku kładziono szczególny nacisk na jakość i wiarygodność pozyskiwanych dowodów — zeznania świadków lub poszkodowanych powinny być zbierane od „bezpośrednio zainteresowanych” na miejscu popełnienia zbrodni; szczególne znaczenie miały ,wszelkie dane mogące zlokalizować i zidentyfikować oddziały lub władze niemieckie" ${ }^{16}$, które mogłyby umożliwić ustalenie odpowiedzialności indywidualnej sprawców.

Utworzenie „rzeczywistego systemu jurysdykcji międzynarodowej, który, z wielu powodów, po wojnie lat 1914-18 pozostał pustą literą"17 postawili sobie za cel uczestnicy zorganizowanej w listopadzie 1941 roku przez polskie ministerstwo spraw zagranicznych konferencji rządów dziewięciu państw okupowanych: Belgii, Czechosłowacji, Francji, Grecji, Holandii, Jugosławii, Luksemburga, Norwegii i Polski. Podczas tego spotkania miał zostać opracowany tekst wspólnej deklaracji o karaniu przestępców wojennych. Punktem wyjścia obrad był przygotowany przez polskich i czechosłowackich prawników projekt rezolucji, na którego treść bez wątpienia wpłynęly wnioski wyciągnięte z lipskiej ,parodii wymiaru sprawiedliwości”. Projekt przewidywał ,ukaranie wszystkich Niemców, którzy popełnili lub popełnią na terytoriach okupowanych przestępstwa przewidziane w ustawodawstwie krajowym lub [dopuścili się - D.U.] naruszeń prawa międzynarodowego" oraz wyłączenie obowiązywania zasady respondeat superior, stwierdzając odpowiedzialność

1945 roku w Londynie zawarte zostało Porozumienie międzynarodowe w przedmiocie ścigania i karania głównych przestępców wojennych Osi Europejskiej, do którego załączona została Karta Międzynarodowego Trybunału Wojskowego (Dz.U. z 1947 r. Nr 63, poz. 367).

15 Projekt instrukcji Komitetu dla Spraw Kraju w sprawie dokumentacji w Polsce działalności okupantów z 21 kwietnia 1940 roku, IPMS, kol. 183/53, przedruk w: Protokoty posiedzeń Komitetu..., s. 289-290. Autorem projektu instrukcji był Michał Potulicki.

16 Ibidem.

${ }^{17}$ Notre texte [...] s'abstient [...] d'échafauder expressis verbis un system, de jurisdiction international qui, pour diverses raisons, était resté lettre-morte apres la guerre de 1914-1918" Protokół konferencji: Conférence des représentants des pays occupés par l'enemi tenue à Londres du 5 au 21 Novembre au Ministère des Affairs Etrangères de la Republique de Pologne, IPMS, A.10.3/3, s. 4-5. Łącznie odbyło się siedem posiedzeń konferencji w polskim MSZ, ostatnie w dniu 2 stycznia 1942 roku, podczas którego przyjęto ostateczny tekst deklaracji z Pałacu św. Jakuba, por. Procès-Verbel de la 7-ème seance [de la Conférence des représentants des pays occupés par l'enemi] du 2 janvier, 1942 à 16 heures, au Ministere des Affaires Etrangères de la Pologne, IPMS, A.10.3/3. 
karną zarówno osób wydających, jak i wykonujących rozkazy ${ }^{18}$. W tekście podkreślono konieczność prowadzenia przez rządy państw-sygnatariuszy dokumentacji zbrodni popełnianych $\mathrm{w}$ ich krajach i kartotek sprawców, niezbędnych do przeprowadzenia w przyszłości ekstradycji podejrzanych i postępowań karnych, aby winni

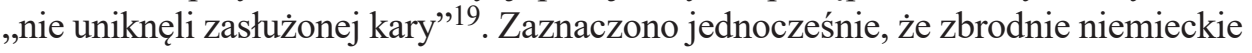
nie mogą być traktowane jako przestępstwa polityczne.

Opracowany podczas listopadowej konferencji tekst wspólnej deklaracji rządów państw okupowanych został ogłoszony 13 stycznia 1942 roku podczas konferencji w Pałacu św. Jakuba (deklaracja z St. James's). W deklaracji państwa-sygnatariusze wśród głównych celów wojny umieściły „ukaranie, w drodze zorganizowanego wymiaru sprawiedliwości, winnych lub odpowiedzialnych za te zbrodnie - czy je nakazali, czy ich dokonali lub w nich uczestniczyli" oraz zdeklarowały „czuwać w duchu solidarności międzynarodowej nad tym, by: a) winni i odpowiedzialni, bez względu na swą przynależność narodową, byli wyszukani, oddani pod sąd i osądzeni, b) zapadłe wyroki były wykonane"20. Sygnatariusze rezolucji potępili „system terroru” wprowadzony w Europie przez Rzeszę Niemiecką i jej sojuszników, podkreślając sprzeczność stosowanych metod prowadzenia wojny i okupacji z zasadami prawa międzynarodowego, w szczególności konwencji haskiej z 1907 roku. Pomimo rezerwy ze strony Wielkiej Brytanii i Stanów Zjednoczonych wobec postulatów wyrażonych w deklaracji z St. James's ${ }^{21}$ jej przyjęcie dawało wyraz solidarności europejskich rządów emigracyjnych i jednoznacznie określało ich stanowisko wobec problemu represji karnej zbrodniarzy wojennych. Postrzegane było również jako wielki sukces gabinetu gen. Sikorskiego, w szczególności polskich dyplomatów, których starania doprowadziły do podpisania deklaracji: Edwarda Raczyńskiego, Władysława Kulskiego i Michała Potulickiego, a także okazja do wzmocnienia roli rządu polskiego jako „przywódcy wszystkich rządów uchodźczych” i „,organizatora kontaktów między aliantami na gruncie londyńskim"22. Przyjęcie deklaracji miało również istotne znaczenie dla polityki wewnętrznej rządu polskiego — już pod koniec lutego

${ }^{18}$ Conférence des représentants des pays occupés..., s. 4.

19 Ibidem, s. 5.

20 T. Cyprian, J. Sawicki, Prawo Norymberskie. Bilans i perspektywy, Warszawa 1948, s. 163. Punishment for War Crimes. The Inter-Allied Declaration Signed at St. James's Palace London on 13th January 1942 and Realtive Documents, document issued by the Inter-Allied Information Centre, London 1942.

21 Pomimo złożenia przez prezydenta USA Franklina D. Roosevelta i premiera Wielkiej Brytanii Winstona Churchilla w październiku 1941 roku oficjalnych oświadczeń potępiających niemieckie okrucieństwa, zawierających dość ogólnikowo sformułowaną zapowiedź „kary za zbrodnie” („retribution for those crimes”), żadne z zachodnich mocarstw ani ZSRR nie przystąpiło do deklaracji z St. James's, co jeszcze bardziej uwydatniło różnice pomiędzy wielkimi mocarstwami a rządami państw okupowanych w ocenie znaczenia problemu represji karnej zbrodniarzy wojennych.

22 M. Hułas, Goście czy intruzi? Rząd polski na uchodźstwie wrzesień 1939-lipiec 1943, Warszawa 1996, s. 290. 
1942 roku postulat ukarania niemieckich zbrodniarzy wojennych został włączony do oficjalnego programu politycznego gabinetu gen. Sikorskiego, zawartego we wspomnianej deklaracji lutowej. Niedługo potem przystąpiono zaś do prac nad treścią aktu prawa wewnętrznego regulującego podstawy materialne i procesowe przyszłych postępowań karnych.

\section{Przygotowania do prac legislacyjnych}

Inicjatorem dyskusji rządowej nad zasadami „prawa proceduralnego i materialnego, na podstawie których sprawa odpowiedzialności indywidualnej niemieckich przestępców zostałaby rozwiązana"23, był Wacław Komarnicki, profesor prawa politycznego i nauki o państwie na Uniwersytecie Stefana Batorego w Wilnie, od 21 stycznia 1942 roku sprawujący urząd ministra sprawiedliwości w rządzie polskim na emigracji. Niedługo po swojej nominacji Komarnicki przystąpił do rozbudowy resortu sprawiedliwości, przy którym utworzył Komisję Prac Ustawodawczych (KPU) ${ }^{24}$ — organ opiniodawczo-doradczy, który z czasem stał się centralnym ośrodkiem opracowywania projektów legislacyjnych Ministerstwa Sprawiedliwości i czyniąc z ministerstwa „instytucję liczącą się i wnoszącą poważny wkład do działalności polskich władz emigracyjnych" ${ }^{25}$. Opracowanie zagadnienia „odpowiedzialności okupantów za zbrodnie i szkody wyrządzone w Polsce" minister Komarnicki zlecił Sekcji V Prawa i Postępowania Karnego i Więziennictwa Komisji Prac Ustawodawczych, której pierwsze posiedzenie, przy udziale Stefana Glasera, Mieczysława Szurleja i Tadeusza Cypriana, odbyło się 8 kwietnia 1942 roku $^{26}$.

23 Archiwum Akt Nowych (dalej: AAN) 2/133/0/6/69, k. 1.

${ }^{24}$ Inauguracyjne posiedzenie KPU odbyło się 28 marca 1942 roku w siedzibie Polish Research Centre w Londynie. Podczas kolejnego zebrania, 1 kwietnia 1942 roku, uchwalono regulamin prac KPU i wybrano przewodniczących sekcji. W skład Komisji Prac Ustawodawczych wchodziło sześć sekcji: I Sekcja Prawa Politycznego (przewodniczący: Tadeusz Brzeski), II Sekcja Ustroju Sądownictwa (przewodniczący: Stanisław Szurlej), III Sekcja Prawa i Postępowania Cywilnego (przewodniczący: Bogdan Nagórski), IV Sekcja Prawa Handlowego i Morskiego (przewodniczący: Bronisław Hełczyński), V Sekcja Prawa i Postępowania Karnego i Więziennictwa (przewodniczący: Stefan Glaser), VI Sekcja Techniki Ustawodawczej (przewodniczący: Ludwik Krajewski). Organizację prac i kompetencje Komisji omawia szczegółowo A. Jankiewicz, op. cit., s. 71-93.

25 Ibidem, s. 14. O powstaniu i rozwoju organizacyjnym resortu sprawiedliwości rządu polskiego na emigracji zob. ibidem, s. 9-39.

${ }^{26}$ AAN 2/133/0/6/44, k. 3. Do problemów wniesionych pod obrady sekcji V należały: kwestia utworzenia obywatelskich sądów honorowych oraz analiza nowel kodeksu karnego, kodeksu postępowania karnego oraz „Związanych z ustawodawstwem karnym ustaw i rozporządzeń podobnej treści, wydanych po roku 1928". Spośród wymienionych zagadnień to dwa pierwsze zdominowały prace sekcji V Komisji Prac Ustawodawczych w pierwszych trzech miesiącach jej istnienia, kiedy to odbyło się dziewięć posiedzeń tego gremium, a pięć z nich poświęconych było wyłącznie pracom nad treścią dekretu prezydenckiego o odpowiedzialności karnej za zbrodnie 
Problematyka dostosowania polskich przepisów karnych do warunków wojennych, utworzenia kodyfikacji niezbędnej do represji karnej zbrodniarzy wojennych oraz współpracy $\mathrm{w}$ tej dziedzinie $\mathrm{z}$ międzynarodowymi gremiami prawniczymi znajdowała się w centrum prac sekcji V KPU, których kierunki zostały określone w opracowanych wiosną 1942 roku Uwagach w przedmiocie zakresu działania i prac Sekcji Prawa Karnego Komisji Prac Ustawodawczych ${ }^{27}$. W myśl tego dokumentu do najważniejszych zadań sekcji V Prawa i Postępowania Karnego i Więziennictwa należały: rewizja projektów ustawodawczych Komisji Kodyfikacyjnej, w szczególności kodeksu karnego i kodeksu postępowania karnego, „celem ich oczyszczenia z późniejszych wadliwych nowelizacji” oraz rewizji „okolicznościowych ustaw karnych dodatkowych”, jak również zbieranie materiałów z dziedziny więziennictwa, przydatnych do przyszłych prac ustawodawczych w tym zakresie. Pozostałe zadania sekcji V dotyczyły bezpośrednio przygotowań polskiego prawodawstwa do przeprowadzenia procesów karnych w sprawach dotyczących przestępstw popełnionych w trakcie działań wojennych lub okupacji. Punkt trzeci uwag włączał do zadań sekcji V KPU „przygotowanie projektów tego rodzaju ustaw, które mogą być celowe z uwagi na nowe okoliczności, względnie sytuacje, spowodowane wydarzeniami wojennymi, a nieprzewidziane przez ustawodawcę $\mathrm{w}$ obowiązujących ustawach [...] poprzez tworzenie nowych, dotąd nieznanych istot czynu przestępnego [...] uwzględniających nowe formy szkodliwej dla interesów państwa czy też jednostek działalności”28. Osobno, w punkcie czwartym, określono potrzebę opracowania ustaw materialnych, procesowych i „dotyczących organizacji sądów” orzekających w sprawach ,przestępstw dokonywanych przez okupanta". Podkreślono jednocześnie bezpośredni związek prac legislacyjnych w zakresie penalizacji zbrodni popełnionych przez okupanta z postanowieniami „deklaracji międzyalianckiej”, czyli deklaracji z Pałacu św. Jakuba, którą traktowano jako istotny argument uzasadniający potrzebę i doniosłość tych prac właśnie ze względu na międzynarodowy kontekst. Kontynuacja dotychczasowego zaangażowania polskich prawników w tym obszarze sugerowana była także w ostatnim, szóstym punkcie omawianego dokumentu, sytuującym wśród zadań Sekcji V KPU ,zajmowanie stanowiska w przedmiocie inicjatywy, wniosków i projektów zgłaszanych przez organizacje międzynarodowe,

wojenne. W pracach tych uczestniczyli Tadeusz Cyprian, Roman Piotrowski, Stanisław Szurlej, następnie do sekcji V KPU dołączyli: Stanisław Celichowski, Wiktor Sukiennicki i Mieczysław Szerer.

27 AAN 2/133/0/6/44, k. 408. W protokole z pierwszego posiedzenia sekcji V KPU z 8 kwietnia 1942 użyta została już pełna nazwa sekcji V: „Prawa i Postępowania Karnego i Więziennictwa”, por. AAN 2/133/0/6/44, k. 3 .

${ }^{28}$ Uwagi w przedmiocie zakresu działania i prac Sekcji Prawa Karnego Komisji Prac Ustawodawczych, AAN 2/133/0/6/44, k. 408. 
a przede wszystkim przez Międzynarodową Komisję dla rekonstrukcji i rozwoju prawa karnego w Cambridge" 29 .

W zamyśle ministra Komarnickiego w ramach Sekcji V Prawa i Postępowania Karnego i Więziennictwa KPU miała zostać utworzona specjalna podkomisja odpowiedzialna wyłącznie za opracowywanie treści dekretu prezydenckiego o karaniu za zbrodnie wojenne ${ }^{30}$. Ze względu na przebieg dalszych prac nad tekstem dekretu jednostka taka nie powstała, jednak to właśnie w Sekcji V Komisji Prawa i Postępowania Karnego i Więziennictwa Komisji Prac Ustawodawczych opracowano pierwotny tekst dekretu, przedstawiony przez Stefana Glasera podczas posiedzenia sekcji V 15 maja 1942 roku, oraz redagowane były jego kolejne wersje.

\section{Prace nad tekstem Dekretu Prezydenta RP o odpowiedzialności karnej za zbrodnie wojenne}

Prace nad tekstem Dekretu Prezydenta o odpowiedzialności karnej za zbrodnie wojenne z dnia 30 marca 1943 roku można podzielić na cztery etapy: 1. obrad Konferencji Międzyministerialnych w ,sprawie odpowiedzialności Niemców za przestępstwa popełnione przez nich na ziemiach okupowanych" w kwietniu 1942 roku; 2. redakcji tekstu i dyskusji nad jego treścią na posiedzeniach Sekcji V Komisji Prawa i Postępowania Karnego i Więziennictwa Komisji Prac Ustawodawczych oraz na posiedzeniach plenarnych KPU w maju i czerwcu 1942 roku; 3. debaty nad treścią dekretu podczas posiedzeń Rady Ministrów w okresie od czerwca do października 1942 roku; 4. obrad nad treścią dekretu Komisji Prawno-Politycznej Rady Narodowej RP w dniach 7 grudnia 1942 i 5 stycznia 1943 roku oraz ostatecznej redakcji tekstu i ogłoszenia dekretu w marcu 1943 roku.

29 Uwagi w przedmiocie zakresu działania i prac Sekcji Prawa Karnego Komisji Prac Ustawodawczych, AAN 2/133/0/6/44, k. 408. Komisja Rekonstrukcji i Rozwoju Prawa Karnego w Cambridge (Cambridge Commission for Penal Reconstruction and Development) została utworzona w listopadzie 1941 roku podczas zorganizowanej na Wydziale Prawa Międzynarodowego Uniwersytetu w Cambridge konferencji brytyjskich prawników i przedstawicieli europejskich państw okupowanych. Prace Komisji koncentrowały się na badaniu ustawodawstw karnych państw europejskich pod kątem przyszłych procesów nazistowskich zbrodniarzy wojennych. Przewodniczącym komisji był profesor prawa międzynarodowego, zastępca rektora Uniwersytetu w Liverpoolu, sir Arnold Mc Nair; z ramienia Polski w jej pracach uczestniczył przewodniczący Sekcji V KPU prof. Stefan Glaser. United Nations War Crimes Commission, History of the United Nations War Crimes Commission and the Development of the Laws of War, London 1948, s. 94-99.

${ }^{30}$ We wnioskach podsumowujących tę konferencję uchwalono, że ,zagadnienia wysunięte na posiedzeniach międzyministerialnej konferencji dla przestępstw wojennych będą kierowane do sekcji karnej Komisji Prac Ustawodawczych celem dalszego opracowania” — AAN 2/133/0/6/69, k. 18. 


\section{Konferencje międzyministerialne w sprawie „odpowiedzialności Niemców za przestępstwa popełnione przez nich na ziemiach okupowanych"}

W dniach 27 i 30 kwietnia 1942 roku miały miejsce obrady zorganizowane przez Komarnickiego w Ministerstwie Sprawiedliwości Konferencji Międzyministerialnych w sprawie „odpowiedzialności Niemców za przestępstwa popełnione przez nich na ziemiach okupowanych" 31 . Zadaniem konferencji było uzgodnienie podstawowych wytycznych określających polskie stanowisko wobec problemu odpowiedzialności Niemców za przestępstwa popełnione w czasie wojny oraz sformułowanie tez, na podstawie których w sekcji V Komisji Prac Ustawodawczych opracowane zostałyby ,zasady prawa proceduralnego i materialnego, na podstawie których sprawa odpowiedzialności indywidualnej niemieckich przestępców zostałaby rozwiązana"32. Dyskutowano również o pogłębieniu współpracy pomiędzy resortami zaangażowanymi w kwestie związane z represją karną zbrodniarzy wojennych: Ministerstwa Sprawiedliwości, Ministerstwa Spraw Wewnętrznych i Ministerstwa Spraw Zagranicznych, których badania i prace w omawianym zakresie powinny w opinii Komarnickiego ,jednolicie reprezentować stanowisko Polski na terenie międzynarodowym"33. W posiedzeniach konferencji uczestniczyli: prof. Wacław Komarnicki, będący jednocześnie przewodniczącym obrad, kierownik Działu Ustawodawczego Ministerstwa Sprawiedliwości prof. Eugeniusz Jarra, radca Prezydium Rady Ministrów dr Ludwik Krajewski, Witold Czerwiński i dr Bernard Ziffer jako przedstawiciele Ministerstwa Informacji i Dokumentacji, kierownik „kartoteki niemieckiej” dr Jan Wagner z ramienia Ministerstwa Spraw Wewnętrznych, Wacław Kulski i dr Michał Potulicki z ramienia Ministerstwa Spraw Zagranicznych, prof. Roman Piotrowski jako reprezentant Biura Prac Politycznych oraz członkowie Komisji Prac Ustawodawczych: dr Tadeusz Cyprian, dr Zygmunt Nagórski, dr Stanisław Szurlej, a wśród nich reprezentujący rząd polski w pracach Cambridge Commission i International London Assembly prof. Stefan Glaser i prof. Bohdan Winiarski.

Jako pierwszy głos w dyskusji zabrał przewodniczący Sekcji V Prawa i Postępowania Karnego i Więziennictwa KPU prof. Stefan Glaser, zwracając uwagę na dwa zasadnicze aspekty problemu odpowiedzialności karnej Niemców za przestępstwa popełnione na ziemiach okupowanych: konieczność zorganizowania odpowiedniego aparatu wymiaru sprawiedliwości oraz potrzebę opracowania przepisów materialnych określających podstawy odpowiedzialności karnej okupantów. Określenie przez rząd polski swojego stanowiska w stosunku do obu tych

31 Protokoły posiedzeń konferencji: AAN 2/133/0/6/69; zob. też: A. Jankiewicz, op. cit., s. 124 -128 .

32 Ibidem.

33 Protokół posiedzenia I konferencji międzyministerialnej z dnia 27 kwietnia 1942 roku, AAN 2/133/0/6/69, k. 1. 
kwestii umocniłoby, w opinii polskiego karnisty, międzynarodową pozycję Polski i dałoby szansę na „ulżenie losom obywateli Rzeczypospolitej” 34 oraz powstrzymanie eksterminacji ludności cywilnej przez prewencyjny charakter ustawodawstwa tego typu. Stefan Glaser wskazywał na skomplikowany charakter problemu prawa proceduralnego i jurysdykcji sądów właściwych do orzekania zarówno w sprawach przestępców wojennych, jak i kwestii prawa materialnego stosowanego w tych postępowaniach. W pierwszym przypadku chodziło o brak sprawdzonego modelu jurysdykcji karnej międzynarodowej oraz ograniczoną moc sprawczą sądownictwa krajowego w dziedzinie ekstradycji. Do mocnych stron sądownictwa międzynarodowego należały: większa bezstronność, obiektywizm oraz ułatwienie przeprowadzenia procedury ekstradycyjnej, szczególnie w wypadku przestępców ukrywających się w państwach neutralnych. Za jurysdykcją sądów krajowych przemawiały zaś względy pragmatyczne: „łatwość ich uruchomienia”35 i gwarancja, że postępowania karne faktycznie zostaną przeprowadzone. Opowiadając się za modelem sądownictwa krajowego, polski poseł przy rządzie belgijskim zwrócił jednocześnie uwagę na problem poruszany już wcześniej na konferencjach międzynarodowych i w tekście deklaracji z St. James's, a więc konieczności podjęcia „przez państwa sprzymierzone decyzji, że przestępcy dopuszczający się zbrodni na terenie państw okupowanych, nie będą traktowani jako przestępcy polityczni i że na żądanie odpowiednich władz będą wydawani”’36.

Druga trudność związana $\mathrm{z}$ prawną regulacją odpowiedzialności karnej zbrodniarzy wojennych polegała na braku norm prawa wewnętrznego i międzynarodowego obejmujących sankcją karną wszystkie przestępstwa popełniane przez okupantów. Niezależnie od tego, czy sądy w sprawach o zbrodnie wojenne miałyby stosować przepisy prawa krajowego czy międzynarodowego, obie grupy regulacji wymagałyby w opinii Stefana Glasera uzupełnienia o nieuwzględniane dotychczas stany faktyczne, co w konsekwencji prowadziłoby do kolizji z zasadą legalizmu, zakazującą retroaktywnego działania prawa: „Ustawa wydana obecnie w związku z popełnionymi przez Niemców przestępstwami, przewidująca nowe formy czynów przestępczych - nie mogłaby dosięgnąć przestępców, ponieważ nie posiadałaby mocy wstecznej" 37 . Z jednej strony Stefan Glaser zdecydowanie opowiadał się za utrzymaniem zasad lex retro non agit i nullum crimen sine lege, których przestrzeganie uważał za podstawowy wyznacznik praworządności

34 Protokoły posiedzeń konferencji: AAN 2/133/0/6/69, k. 3.

35 Ibidem.

36 AAN 2/133/0/6/69, k. 3. W deklaracji z Pałacu św. Jakuba państwa-sygnatariusze oświadczały, że „1. Gwałty dokonywane na ludności cywilnej pozostają w sprzeczności z powszechnie przyjętymi poglądami narodów cywilizowanych dotyczących prowadzenia działań wojennych i przestępstw politycznych; [...] 4. Są zdecydowane [...] dopilnować, aby winni i odpowiedzialni — niezależnie od ich narodowości — zostali wykryci, oddani w ręce sprawiedliwości i osadzeni, a wyroki na nich wykonane".

37 AAN, MS Emigr., sygn. 69, k. 2. 
danego systemu prawnego ${ }^{38}$. Z drugiej zaś rozpoczął kierowanie swoich rozważań ku określeniu faktycznego znaczenia i celowości zakazu wstecznej mocy obowiązującej prawa oraz ku pytaniu o funkcje ochronne prawa oraz o wartości podlegające jego bezwzględnej ochronie. Polski karnista jednoznacznie stwierdzał, że „odpowiedzialność przestępców [wojennych — D.U.] musi być jak najbardziej skuteczna i realna, a z nią i wymiar sprawiedliwości”39. Właśnie względom pragmatycznym dawał pierwszeństwo, poddając pod dyskusję bezwzględną moc obowiązującą zasady lex retro non agit, konstatując, iż ,gdyby można było przeforsować »naruszalność« [tej zasady — D.U.], rozwiązanie kwestii ekstradycji byłoby prostsze i skuteczniejsze" 40 .

Radca Ministerstwa Spraw Zagranicznych i jeden z autorów tekstu deklaracji z Pałacu św. Jakuba, dr Michał Potulicki, zaznaczał w swoim wystąpieniu podczas konferencji międzyministerialnej, że represja karna zbrodniarzy musi być oparta na trwałych i solidnych podstawach prawnych oraz przedstawił trzy możliwe sposoby ich określenia: 1. poprzez powołanie się na przepisy konwencji haskiej z 1907 roku oraz na zwyczaj międzynarodowy (lex lata internationalis), 2. poprzez opracowanie „kodeksu karnego międzynarodowego” będącego kompilacją konwencji haskiej i narodowych ustaw karnych, który uwzględniałby „zasady etyki i moralności międzynarodowej”, jak i „charakterystykę działań przestępnych, które miały miejsce w obecnej toczącej się wojnie" ${ }^{11}$ (lex ferenda internationalis) lub 3. stosując przepisy prawne państwa, w którym popełniono przestępstwo.

W ocenie Potulickiego zastosowanie pierwszego z zaproponowanych rozwiązań nie było wskazane z powodu zbyt ogólnego charakteru międzynarodowego prawa zwyczajowego, nieprecyzyjnego określenia znamion czynów przestępnych w konwencji haskiej oraz ze względu na brak sankcji i jurysdykcji w odniesieniu do zawartych w niej przepisów. Regulacje konwencji z 1907 roku o prawach i zwyczajach prowadzenia wojny miały kluczowe znaczenie dla ustalenia, „czy dany czyn jest, czy nie jest usprawiedliwiony przez stan wojenny", jednak nie dawały gwarancji, by „sprawnie i z pewną konieczną jednolitością orzecznictwa sądzić wypadki, które będą do osądzenia"42.

Przyjęcie drugiego rozwiązania i określenie treści przepisów właściwych do sądzenia zbrodniarzy wojennych de lege ferenda internationale miałoby natomiast doniosłe znaczenie procesowe - pozwoliłoby dość precyzyjnie określić

38 S. Glaser, Nullum crimen sine lege, ,Journal of Comparative Legislation and International Law" 24, 1942, nr 1, s. 29-37.

39 Protokół posiedzenia Konferencji Międzyministerialnej z dnia 30 kwietnia 1942 roku, s. 2, AAN, MS Emigr., sygn. 69, k. 2.

40 Protokół AAN 2/133/0/6/69, k. 17.

41 Referat dr Michała Potulickiego wygłoszony podczas posiedzenia Konferencji Międzyministerialnej 27 kwietnia 1942 roku, AAN 2/133/0/6/69, k. 21.

42 Ibidem. 
znamiona ściganych przestępstw oraz rodzaje kar, czego konsekwencją byłoby ujednolicenie doktryny i orzecznictwa w odniesieniu do strony przedmiotowej i podmiotowej przestępstw, jak i zakresu sankcji karnych. Przeciw tworzeniu nowego aktu prawa karnego międzynarodowego o wstecznej mocy obowiązującej przemawiała wspomniana już zasada lex retro non agit, której łamanie właśnie na gruncie prawa karnego ${ }^{43}$ przez władze okupacyjne w stosunku do ludności ziem okupowanych stanowiło jeden z głównych argumentów dowodzących zbrodniczego i bezprawnego charakteru niemieckiej okupacji. „Trudno sobie wyobrazić, abyśmy przyjmowali jako punkt wyjścia to, co krytykujemy u wroga"44 — konkludował dyplomata. Również względy praktyczne związane z techniką tworzenia prawa międzynarodowego, dużą liczbą zainteresowanych stron i narodowych ustaw karnych, które należałoby uwzględnić w skonstruowanym wedle przedstawionej koncepcji „kodeksie międzynarodowym”, stanowiły faktyczną przeszkodę w przyjęciu proponowanej metody. W tym punkcie z argumentacją Michała Potulickiego w pełni zgadzał się prof. Bohdan Winiarski, który uważał pomysł kompilacji kodeksów karnych za niewskazany „,ze względu na trudności natury

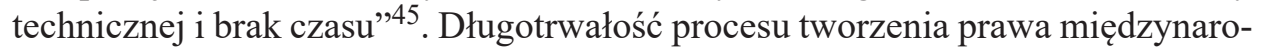
dowego, liczba uczestniczących w nim stron, a także specyfika prawa narodów ${ }^{46}$ utrudniłyby według niego opracowanie w krótkim czasie ścisłych i precyzyjnych przepisów prawnych określających sankcje karne i zasady jurysdykcji, a znalezienie pewnego i efektywnego rozwiązania uważał za priorytet. Podobnego zdania był Zygmunt Nagórski, który przekonywał, że ,przyjęcie tezy ułożenia międzynarodowego prawa karnego jest możliwe li-tylko w czasie pokoju, nie zaś w obecnym stanie wojennym, gdyż opracowanie takowego jest najeżone specjalnymi trudnościami natury politycznej i naukowej, i wymaga poświęcenia specjalnie dużo czasu" ${ }^{47}$. Zamiast tworzyć nowe przepisy ujmujące wszystkie zaistniałe stany faktyczne, Nagórski proponował podniesienie istniejących sankcji przewidzianych w polskim kodeksie karnym z 1932 roku.

43 Por. A. Wrzyszcz, Okupacyjne sądownictwo niemieckie w Generalnym Gubernatorstwie. 1939-1945. Organizacja i funkcjonowanie, Lublin 2008, s. 44 n.

44 Referat dr Michała Potulickiego wygłoszony podczas posiedzenia Konferencji Międzyministerialnej 27 kwietnia 1942 roku, AAN 2/133/0/6/69, k. 22.

45 Protokół Posiedzenia Konferencji Międzyministerialnej z dnia 30 kwietnia 1942 roku, s. 5, AAN 2/133/0/6/69, k. 16.

46 Na długotrwałość procesu kształtowania się prawa międzynarodowego Bohdan Winiarski zwracał uwagę w licznych publikacjach, między innymi w pracy Bezpieczeństwo, arbitraż, rozbrojenie z 1928 roku, w której konstatował: „Gwarancją rozwoju prawa narodów — a bez niego niepodobna sobie wyobrazić rozwoju sądownictwa międzynarodowego - jest kształtowanie się tego prawa swobodne i z natury rzeczy powolne w zależności od równie powoli rozwijającego się poczucia prawnego narodów i w miarę uzgadniania ich rzeczywistych potrzeb i interesów" - idem, Bezpieczeństwo, arbitraż, rozbrojenie, Poznań 1928.

47 Protokół posiedzenia Konferencji Międzyministerialnej z dnia 27 kwietnia 1942 roku, AAN 2/133/0/6/69, k. 8 . 
Trzecia z propozycji Michała Potulickiego, a więc zastosowanie przepisów prawa karnego wewnętrznego państwa, na którego terytorium popełniono zbrodnie, i uzupełnienie ich o ,istniejące instrumenty prawa międzynarodowego", zawarte w traktacie wersalskim i konwencji haskiej, została uznana przez uczestników kwietniowej konferencji międzyministerialnej za najtrafniejsze rozwiązanie dla „wykonania zasady styczniowej Deklaracji” (deklaracji z St. James's). Stosowanie prawa miejsca popełniania przestępstwa, niezależnie od obywatelstwa oskarżonego, stwarzało w opinii Potulickiego solidną podstawę prawną w postaci już istniejących przepisów karnych oraz gwarantowało nienaruszenie zasady lex retro non agit. Posłużenie się przepisami prawa krajowego w znacznej mierze rozwiązałoby, jak przekonywał polski dyplomata, najtrudniejsze problemy związane z represją karną zbrodniarzy wojennych, a więc działania na rozkaz oraz odpowiedzialności karnej podżegaczy i pomocników. W pierwszym przypadku polski kodeks karny dawał wystarczające podstawy do eliminacji nadużycia argumentu obrony „działania na rozkaz” poprzez możliwość zbadania w trakcie postępowania okoliczności przestępstwa popełnionego z rozkazu władzy przełożonej i sprawdzenia występowania przesłanek wyłączających odpowiedzialność karną sprawcy — przymusu nieodpartego (vis absoluta, art. 19 k.k.), obrony koniecznej (art. 21 k.k) czy stanu wyższej konieczności (art. 22 k.k.). „Wyjątek na korzyść obwinionego może zaistnieć wtedy, i tylko wtedy, gdy zbadawszy, jaka to władza rozkaz wydała i jaki był rodzaj rozkazu, i sposób, i okoliczności wykonania czynu — sędzia dojdzie do przekonania, że autor nie był w stanie przeciwstawić się rozkazowi otrzymanemu. [...] W tych wypadkach sędziowie otrzymują dość szeroką marżę dla oceny konkretnej takiego wypadku"48. Również art. 26-29 polskiego kodeksu karnego, określające zasady odpowiedzialności karnej za podżeganie i pomocnictwo, a w szczególności art. 28 wprowadzający w tych przypadkach zasade ,indywidualizacji winy" ${ }^{49}$, w ocenie Potulickiego stanowily dostateczne podstawy prawne do postawienia zarzutów karnych osobom współdziałającym w przestępstwie.

Odmiennie regulacje polskiego kodeksu karnego w omawianym zakresie ocenił radca Prezydium Rady Ministrów i przewodniczący sekcji VI Komisji Prac Ustawodawczych, dr Ludwik Krajewski, który przekonywał, że posłużenie się przepisami krajowymi ograniczy jednocześnie odpowiedzialność osób ze względu na nieuwzględnienie $w$ tych przepisach większości popełnianych przestępstw.

48 Ibidem.

49 Art. 28 k.k.: Podżegacz i pomocnik ponoszą odpowiedzialność w granicach swego zamiaru, niezależnie od odpowiedzialności osoby, która zamierzonego czynu dokonała lub miała dokonać (Dz.U. poz. 571 i 572). Zob. także komentarz Juliusza Makarewicza do omawianego paragrafu: „Przepis 28 zawiera najistotniejszą część konstrukcji prawnej, dotyczącej podżegacza i pomocnika. [...] Są [oni - D.U.] indywidualnościami odpowiadającymi w granicach własnego zamiaru. Podżegacz i pomocnik odpowiadają za swe działanie nawet wtedy, gdy osobnik, który miał być sprawcą nie odpowiada, ponieważ nie przedsięwziął żadnego działania" - idem, Kodeks karny z komentarzem, wydanie piąte, Lwów 1938, s. 137. 
Zwracał on uwagę na problemy, które znalazły się w centrum dyskusji na dalszych etapach prac nad dekretem Prezydenta RP o odpowiedzialności karnej za zbrodnie wojenne, przede wszystkim na systemowy charakter niemieckich zbrodni i wynikające $\mathrm{z}$ tego trudności w ustaleniu sprawcy (sprawców) danego przestępstwa i przypisania (im) mu winy, oraz na fakt, że wprowadzony na ziemiach polskich wcielonych do Rzeszy oraz w Generalnym Gubernatorstwie nowy system prawny legitymizował większość przestępczych działań niemieckich władz administracyjnych, wojskowych oraz wymiaru sprawiedliwości. Ponadto dopuszczane przez polski kodeks karny kontratypy określające okoliczności wyłączające bezprawność czynu stwarzały w opinii Ludwika Krajewskiego możliwości uniknięcia odpowiedzialności przez wielu oskarżonych, na przykład funkcjonariuszy niższego szczebla zobligowanych na mocy stosunku służbowego do wykonywania rozkazów swoich przełożonych i działających „pod przymusem i w obronie własnego życia”50.

$\mathrm{Z}$ kolei według prof. Romana Piotrowskiego problem wyłączenia przestępności czynu w przypadku działania na rozkaz w sposób jednoznaczny rozwiązywał przepis art. 9 kodeksu karnego wojskowego, stanowiący, iż sprawca podlega odpowiedzialności karnej, jeśli dopuszczając się czynu będącego wykonaniem rozkazu w sprawach służbowych, wiedział o tym, ,że rozkaz dotyczył czynu, stanowiącego

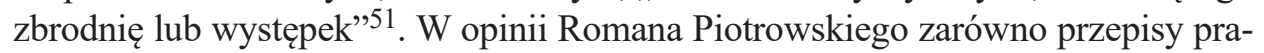
wa międzynarodowego - konwencji haskiej i traktatu wersalskiego, jak i polski kodeks karny oraz kodeks karny wojskowy w stopniu wystarczającym określały podstawy materialne i procesowe postępowań karnych w sprawach o popełnienie przez członka wojsk obcych lub administracji cywilnej zbrodni w trakcie działań wojennych lub okupacji. Jak przekonywał Piotrowski, konwencja haska precyzyjnie określiła „nieprawność działania obcej armii na terenach okupowanych w ten sposób, że dopóki członek tej armii wykonuje zlecenia przełożonych w ramach dozwolonych przez Konwencję, dopóty działania jego są uznane za prawne i jest on broniony przez przepisy tejże Konwencji, z chwilą zaś, kiedy się wyłamie spod jej zakazów, jest wyjęty z poza prawa i podpada jurysdykcji krajowej”52. Właściwość sądów krajowych do rozpatrywania spraw o popełnienie „czynu przeciw prawom i zwyczajom wojennym" na terenie danego państwa i „trybunałów mieszanych” w przypadkach, gdy oskarżony działał na terenie kilku państw, jak i obowiązek wydania oskarżonych określone zostały w art. 227 i 228 traktatu wersalskiego ${ }^{53}$,

50 Protokół posiedzenia Konferencji Międzyministerialnej z dnia 30 kwietnia 1942 roku, s. 2 , AAN 2/133/0/6/69, k. 17.

51 Rozporządzenie Prezydenta Rzeczypospolitej z dnia 21 października 1932 roku — Kodeks karny wojskowy, Dz.U. z 1932 r. Nr 91, poz. 765.

52 Protokót..., s. 2, k. 13. Piotrowski odnosił się do art. 3 konwencji haskiej, stanowiącego: „Strona wojująca, któraby naruszyła postanowienia powyższego regulaminu, będzie pociągnięta do indemnizacji, jeśli tego zajdzie potrzeba. Strona ta będzie odpowiedzialną za każdy czyn osób, wchodzących w skład jej siły zbrojnej”.

53 Traktat pokoju między mocarstwami sprzymierzonemi i skojarzonemi i Niemcami, podpisany w Wersalu dnia 28 czerwca 1919 roku, art. 227-229, Dz.U. z 1920 r. Nr 35 poz. 200. 
które powinny znaleźć zastosowanie do przestępstw popełnionych podczas II wojny światowej. Zakres mocy obowiązującej polskiej ustawy karnej został sformułowany w ocenie Piotrowskiego w rozdziale I polskiego kodeksu karnego w sposób dający solidne podstawy ujęcia przestępców niebędących obywatelami państwa polskiego czy działających poza jego granicami. W myśl art. 3 §1 k.k. polskiej ustawie karnej podlegały wszystkie osoby, „które popełniły przestępstwo na obszarze Państwa Polskiego albo na polskim statku wodnym lub powietrznym" ${ }^{24}$. Natomiast art. 5 rozszerzał terytorialną moc obowiązywania kodeksu: „Ustawę karną polską stosuje się do cudzoziemców, którzy popełnili za granicą przestępstwo, skierowane przeciw dobru lub interesom Państwa Polskiego, obywatela polskiego lub polskiej osoby prawnej" 55 . Warunkiem ścigania w oparciu o przepisy prawa polskiego było w tych wypadkach ,uznanie [...] czynu za przestępstwo przez ustawę obowiązującą w miejscu popełnienia" (art. 6). Zgodnie z art. 8 k.k. bez względu na przepisy obowiązujące w miejscu popełnienia czynu i na obywatelstwo sprawcy polski kodeks karny znajdował jednak zastosowanie „,do osób, które popełniły za granicą a) przestępstwo przeciwko bezpieczeństwu wewnętrznemu lub zewnętrznemu Państwa Polskiego; b) przestępstwo przeciwko urzędom lub urzędnikom państwa polskiego; c) fałszywe zeznania złożone wobec urzędu Państwa Polskiego"56.

Wymienione w części ogólnej kodeksu karnego „przestępstwa przeciwko bezpieczeństwu wewnętrznemu i zewnętrznemu państwa" nie zostały sformułowane w formie definicji legalnej w przepisach szczegółowych ustawy karnej, jednak do przestępstw tych zaliczano zbrodnie stanu (rozdział XVII k.k.), przestępstwa przeciw interesom państwa i stosunkom międzynarodowym (rozdział XVIII k.k.), jak i przestępstwa związane ze zdradą stanu i zdradą tajemnicy wojskowej, określone w Rozporządzeniu Prezydenta RP z dnia 24 października 1934 roku o niektórych przestępstwach przeciwko bezpieczeństwu państwa ${ }^{57}$. Do wymienionych już przestępstw, „których dopuścił się okupant niemiecki”, a które przewidziane były przez polski kodeks karny, dr Tadeusz Cyprian włączył podczas obrad kwietniowej konferencji niektóre z przestępstw przeciwko porządkowi publicznemu, określone w rozdziale XXV ustawy — „publiczne lżenie lub wyszydzanie Narodu albo Państwa Polskiego” (art. 152 k.k.), „znieważenie symboli państwowych” (art. 153 k.k.) oraz „publiczne nawoływanie do popełnienia przestępstwa" (art. 154 k.k.). Cyprian dostrzegał braki przepisów prawa wewnętrznego, które nie ujmowały precyzyjnie przedmiotowej strony wszystkich popełnianych przez okupanta zbrodni, uważał jednak, że ,inne stany faktyczne mogą być podciągnięte pod odpowiedzialność z jednego z wyżej wymienionych

54 Por. art. art. 3,5 i 6 kodeksu karnego z 1932 roku.

55 Ibidem.

56 Ibidem.

57 Rozporządzenie Prezydenta Rzeczypospolitej z dnia 24 października 1934 roku o niektórych przestępstwach przeciwko bezpieczeństwu państwa, Dz.U. z 1934 r. Nr 94, poz. 851. 
artykułów" ${ }^{\text {58 }}$. Posłużenie się przepisami prawa karnego wewnętrznego Tadeusz Cyprian uważał za najpewniejsze rozwiązanie w sytuacji braku precyzyjnych przepisów obowiązującego prawa międzynarodowego, regulujących problem odpowiedzialności za zbrodnie popełnione w czasie wojny. „Chodzi o stworzenie systemu w praktyce dającego wyniki, a nie o czystość konstrukcji prawniczych" ${ }^{59}$, przekonywał, zaznaczając jednocześnie, że sama idea ścigania — a w przyszłości i sądzenia - zbrodniarzy wojennych, nawet w oparciu o już istniejące ustawy krajowe, nie zyskała jeszcze pełnego poparcia ze strony rządu brytyjskiego i amerykańskiego, „drażliwych bardzo na punkcie pojęcia »odwetu«"60.

Do kwestii tej nawiązał także Władysław Kulski, zwracając uwagę zebranych na potrzebę kontynuowania akcji informacyjnej o dokonywanych w Polsce zbrodniach i przekonania wszystkich aliantów o zasadności represji karnej zbrodniarzy wojennych ${ }^{61}$. Zdaniem radcy prawnego polskiego Ministerstwa Spraw Zagranicznych obrady konferencji międzyministerialnej powinny ograniczyć się do trzech punktów: zawarcia „klauzuli karalności przestępców” w rozejmie, przeanalizowania zakresu jurysdykcji sądów narodowych oraz opracowania koncepcji ekstradycji gwarantującej wydanie sprawców z Rzeszy, zarówno państw neutralnych, jak i państw sprzymierzonych. W sprawie ustalania zasad ekstradycji szef polskiego sądownictwa wojskowego i przewodniczący Stowarzyszenia Prawników Polskich w Zjednoczonym Królestwie, mecenas Stanisław Szurlej, zalecał skupić się na gwarancji wydania oskarżonych na żądanie państwa sprzymierzonego, na „wypełnieniu zobowiązań ex delicto”, czyli na uwzględnieniu „skutków prawno-cywilnych, spowodowanych zbrodniczym działaniem nieprzyjaciela” oraz na „zabezpieczeniu wykonania tych warunków przez okupację kraju do czasu wyrównania krzywd"62.

Jak wynika z przytoczonych wypowiedzi, uczestnicy konferencji międzyministerialnej w sprawie odpowiedzialności Niemców za zbrodnie popełnione w czasie wojny opowiadali się za stosowaniem w sprawach o zbrodnie wojenne przepisów prawa krajowego. Zgadzano się, że w ten sposób możliwe byłoby uniknięcie jakiejkolwiek kolizji z zakazem retroaktywnego działania prawa, jednak wyrażony przez Stefana Glasera pogląd, że ,gdyby można było przeforsować »naruszalność« [zasady lex retro non agit - D.U.], rozwiązanie kwestii ekstradycji byłoby prostsze i skuteczniejsze" 63 , nie był pod żadnym względem odosobniony. Otwarte pozostało pytanie, czy stany faktyczne i sankcje przewidziane w przepisach polskiego kodeksu karnego były wystarczające do skutecznego ukarania zbrodniarzy wojennych,

58 Protokół posiedzenia Konferencji Międzyministerialnej z dnia 30 kwietnia 1942 roku, s. 2 , AAN 2/133/0/6/69, k. 12.

59 Ibidem.

60 Ibidem.

61 Ibidem, k. 16.

62 Ibidem, k. 17.

${ }^{63}$ Ibidem. 
a zatem pytanie o celowość uzupełnienia ustawodawstwa krajowego o ustawę specjalną precyzującą zasady pociągania do odpowiedzialności karnej sprawców naruszeń praw i zwyczajów prowadzenia wojny. Różnice w ocenie tego problemu były widoczne zarówno podczas dyskusji, jak i we wnioskach podsumowujących konferencję. Przewodniczący obradom prof. Eugeniusz Jarra podsumował zebranie, stwierdzając, że zagadnienia dotyczące odpowiedzialności karnej zbrodniarzy wojennych powinny być omawiane $\mathrm{w}$ dalszym ciągu na forum konferencji międzyministerialnej przy Ministerstwie Sprawiedliwości, zaś w sposób szczegółowy opracowywane przez Sekcję V KPU Prawa i Postępowania Karnego i Więziennictwa. Jak zaznaczał Jarra, „Ministerstwo Sprawiedliwości podziela stanowisko, wypowiadające się za tym, aby dla ogółu przestępstw miały zastosowanie sądy własne oraz kodeksy narodowe, dla głównych zaś przestępców - Trybunał Międzyaliancki" ${ }^{64}$. Kwestia stosowanych w postępowaniach karnych przepisów miała zostać zbadana na forum sekcji V KPU. Na wniosek przedstawicieli Ministerstwa Spraw Zagranicznych w podsumowaniu konferencji międzyministerialnej opowiedziano się za utrzymaniem zasady lex retro non agit oraz za stosowaniem w sprawach o zbrodnie wojenne, ,zasad ustawodawstwa wewnętrznego w połączeniu z prawem międzynarodowym" ${ }^{\prime \prime}$.

\section{Debata nad tekstem dekretu w Sekcji V Prawa \\ i Postępowania Karnego i Więziennictwa oraz na posiedzeniach plenarnych Komisji Prac Ustawodawczych}

Artykuł 1 stanowił iż, „kto wbrew zasadom prawa międzynarodowego działa w Polsce lub zagranicą na szkodę interesu publicznego Państwa Polskiego, interesu polskiej osoby prawnej lub interesu prywatnego obywatela polskiego, ulega karze więzienia" ${ }^{66}$. Zaostrzenie sankcji do kary dożywotniego pozbawienia wolności lub kary śmierci było przewidziane w sytuacjach, gdy czyn określony w art. 1 spowodował śmierć, chorobę fizyczną lub psychiczną, pozbawienie wolności na okres jednego miesiąca, wysiedlenie lub przesiedlenie obywatela polskiego (art. 2) lub wywoła ,niebezpieczeństwo powszechne dla życia i zdrowia ludzkiego w Polsce" (art. 3) ${ }^{67}$.

W myśl art. 4 omawianego projektu dekretu kara dożywotniego więzienia groziła za sprzeczne $\mathrm{z}$,zasadami prawa międzynarodowego" zmuszenie

64 Ibidem.

65 Ibidem.

66 Dekret o karaniu za niektóre zbrodnie dokonane w czasie wojny. Tekst przedłożony na posiedzenie Sekcji Prawa Karnego w dn. 15 maja 1942 roku, AAN 2/133/0/6/44, k. 12.

${ }^{67}$ Ibidem, k. 11. 
obywatela polskiego do „wstąpienia do wojska obcego lub do pracy dla nieprzyjaciela”68. Artykuł 5 stanowił zaś, iż: „Kto w Polsce lub zagranicą wyrokuje w stosunku do obywatela polskiego na podstawie przepisów prawnych, wydanych wbrew przepisom prawa międzynarodowego, ulega karze więzienia" ${ }^{99}$. Jeśli wyrok taki spowodowałby skutki przewidziane w art. 2 i 3, kara ulegała zaostrzeniu do dożywotniego pozbawienia wolności lub kary śmierci (art. 6). Regulacje art. 7 i 8 stanowiły próbę rozwiązania problemu interpretacyjnego przepisów prawa wewnętrznego, dotyczących działania na rozkaz jako okoliczności wyłączającej przestępność czynu. Artykuł 7 zawierał klauzulę generalną stwierdzającą, że „do czynów objętych niniejszym dekretem mają odpowiednie zastosowanie przepisy części ogólnej k.k., o ile przepisy niniejsze nie stanowią inaczej" ${ }^{\prime 70}$. Natomiast w myśl art. 8 sankcjom określonym w omawianym dokumencie podlegał ,zarówno ten, kto wydaje rozkaz dokonania czynu przewidzianego w niniejszym dekrecie, jak i ten, kto rozkaz ten wykonywa"71. Kwestie proceduralne zostały uregulowane w pierwszym projekcie dekretu w art. 9 stwierdzającym, iż ,sprawy o przestępstwa objęte niniejszym dekretem należą do właściwości Sądów Apelacyjnych wyrokujących w pierwszej instancji" ${ }^{2}$. Szczegóły dotyczące właściwości miejscowej i rzeczowej sądów ani postępowania apelacyjnego nie zostały doprecyzowane. Artykuł 10 określał moc obowiązującą przepisów w czasie i stanowił, że „Dekret niniejszy dotyczy czynów popełnionych po dniu 31 sierpnia 1939 r."73. Wykonanie przepisów dekretu zostało powierzone na podstawie art. 11 solidarnie Ministrowi Sprawiedliwości i Ministrowi Spraw Wewnętrznych.

Poddając projekt dekretu pod dyskusję członków sekcji V Komisji Prac Ustawodawczych, Stefan Glaser podkreślał, że jest zdecydowanym zwolennikiem przestrzegania zasad nullum crimen sine lege i lex retro non agit, które oceniał jako fundamentalne gwarancje bezpieczeństwa obywateli przed nadużyciami władzy i możliwymi manipulacjami wymiarem sprawiedliwości. Wyjątkowość sytuacji, w jakiej znalazło się społeczeństwo polskie pod okupacją, pozbawione ochrony prawa międzynarodowego oraz krajowego, uzasadniała jednak, w drodze wyjątku, odstąpienie od tej zasady. Istotnym argumentem przywoływanym przez Stefana Glasera był ,polityczno-propagandowy” wydźwięk ogłoszenia dekretu penalizującego zbrodnie popełniane w czasie wojny i przekonanie o prewencyjnym działaniu tego aktu prawnego. W jego ogłoszeniu polski karnista widział „możność ulżenia losom rodaków” znajdującym się pod okupacją niemiecką. ,Jeżeli ogłoszony w Kraju dekret powstrzyma chociażby niektórych Niemców od popełnienia kolejnych zbrodni, to dekret taki spełni swoje zadanie

\footnotetext{
68 Ibidem, k. 12.

69 Ibidem.

70 Ibidem.

71 Ibidem.

72 Ibidem.

73 Ibidem.
} 
i jest uzasadniony" ${ }^{94}$. Glaser nie obawiał się również o reakcję międzynarodowych środowisk prawniczych na wydanie przez rząd polski w zaistniałej sytuacji specjalnej ustawy karnej i konkludował, że „odstąpienie od ogólnie przyjętej $\mathrm{w}$ prawie zasady lex retro non agit nie wywoła w opinii angielskiej specjalnego oburzenia i oporu, skoro bogata angielska literatura prawnicza traktuje niejednokrotnie bezprawne czyny, nie objęte żadną ustawą, jako przestępstwa" 75 .

Zgoła odmiennie projekt dekretu oceniał nieobecny na posiedzeniu Sekcji V KPU prof. Roman Piotrowski, którego uwagi do art. 8 i 11 przedstawił zebranym Tadeusz Cyprian. W proponowanym brzmieniu art. 8 nie uchylał, zdaniem Piotrowskiego, stanu wyższej konieczności i utrzymywał możliwość zastosowania klasycznej linii obrony oskarżonych. Za słabą stronę dokumentu uważał także „podważanie odwiecznej prawnej zasady" żenie dotyczyło międzynarodowego wydźwięku publikacji tego dokumentu: „,bez uprzedniego porozumienia $\mathrm{z}$ właściwymi czynnikami angielskimi nie można ogłaszać dekretu, ponieważ dekret ten ma charakter aktu politycznego i niezasięgnięcie opinii może wywołać nieprzyjemne skomplikowanie w stosunkach z Aliantami" "77, a nawet utrudnienie w przyszłości wdrożenia procedury ekstradycyjnej. Potrzeby czy obowiązku konsultowania się z aliantami nie widzieli po stronie polskiej Stefan Glaser i Stanisław Szurlej. Naczelny Prokurator Wojska Polskiego sądził wprawdzie, że „wypada przesłać Rządowi Angielskiemu sformułowanie motywów przemawiających za jego wydaniem", był jednak przeciwny zwracaniu się do władz z prośbą o wyrażenie zgody na publikację dekretu ${ }^{78}$. „Ze względu na to, że Dekret miałby obowiązywać tylko na terenie państwa polskiego”, argumentował zaś Stefan Glaser, „władze polskie nie powinny być krępowane polityką aliantów".

Oprócz obiekcji merytorycznych zgłoszonych przez Romana Piotrowskiego podczas omawianego posiedzenia sekcji V Prawa i Postępowania Karnego i Więziennictwa KPU swoje zastrzeżenia dotyczące redakcji i strony językowej dekretu zgłosił dr Stanisław Szurlej. Jego uwagi dotyczyły braku jednolitości pojęć używanych w art. 1, 4 i 5. W art. 1 i 4 posłużono się terminem ,zasady prawa międzynarodowego" (,kto wbrew zasadom prawa międzynarodowego”), w art. 5 zaś terminem ,przepis prawa międzynarodowego” („Kto wyrokuje w stosunku do obywatela polskiego na podstawie przepisów prawnych, wydanych wbrew przepisom prawa międzynarodowego") ${ }^{79}$. Stanisław Szurlej postulował używanie we wszystkich przepisach jednego pojęcia, mianowicie „zasady”, jako

74 Protokół posiedzenia Sekcji Prawa i Postępowania Karnego i Więziennictwa z dnia 15 maja 1942 roku, AAN 2/133/0/6/44, k. 6.

75 Ibidem.

76 Ibidem.

77 Ibidem.

78 Ibidem, k. 7.

79 Ibidem. 
terminu o szerszym znaczeniu i zastosowaniu ${ }^{80}$. Za rozwiązaniem tym opowiedział się także Eugeniusz Jarra, przypominając, że ,użyte w dekrecie pojęcie »zasada" odpowiada najzupełniej terminologii prawa międzynarodowego, które w aktach międzynarodowych, np. w Traktacie Wersalskim, powołuje się nawet na zasady prawa natury" ${ }^{\prime 1}$. Postulat ujednolicenia pojęć używanych w zakresie odwołań do prawa międzynarodowego został podczas posiedzenia sekcji V Prawa i Postępowania Karnego Komisji Prac Ustawodawczych rzeczywiście przyjęty. W tekście projektu dekretu, uchwalonym na zebraniu sekcji V w dniu 15 maja 1942 roku, nie posłużono się jednak ani pojęciem ,zasad prawa międzynarodowego", ani „przepisu prawa międzynarodowego”, które we wszystkich przywołanych artykułach (art. 1, art. 4 i art. 5 projektu dekretu) zostały zastąpione pojęciem „norm prawa międzynarodowego".

Problem wykładni tych artykułów dekretu, które odsyłały do norm prawa międzynarodowego, podjął na zebraniu Sekcji VI Techniki Ustawodawczej Komisji Prac Ustawodawczych 28 maja 1942 roku, zwołanego w celu redakcji opracowywanego aktu prawnego zgodnie założeniami techniki ustawodawczej ${ }^{82}$, sędzia Sądu Najwyższego dr Ignacy Baliński. Użyte sformułowanie uważał za zbyt ogólne i spodziewał się, że w trakcie stosowania prawa sędziowie będą mieć problemy z wykładnią pojęcia ,norm prawa międzynarodowego" i wątpliwości co do tego, jakie prawo powinno być brane pod uwagę przy badaniu konkretnych stanów faktycznych ${ }^{83}$. Profesorowie Bohdan Winiarski i Bronisław Hełczyński uważali, że terminy „prawa krajowego" i „prawa międzynarodowego" są „,całkowicie jasne i nie mogą być poddawane w wątpliwość" 84 . Winiarski zaproponował jednak doprecyzowanie tekstu dekretu przez dodanie sformułowania ,wbrew normom zwyczajowego i umownego prawa międzynarodowego"; ostatecznie brzmienie tych artykułów pozostało jednak bez zmian. Podczas omawianego posiedzenia Sekcji VI Techniki Ustawodawczej do pierwotnego tekstu zostały dodane dwa artykuły: art. 10 regulujący kwestię biegu terminów przedawnienia, stwierdzający, iż „,bieg terminów przedawnienia, przewidzianych w art. 86 kodeksu karnego rozpoczyna się z chwilą wznowienia czynności Sądu Najwyższego" oraz zawarty w art. 13 przepis wprowadzający ustawę, stanowiący, że „Dekret niniejszy wchodzi w życie z dniem ogłoszenia"85. Artykuł 9 , zawierający przepisy procesowe, został uzupełniony o trzy dodatkowe

${ }^{80}$ Ibidem.

81 Ibidem, k. 7.

82 Protokół z posiedzenia Sekcji VI Techniki Ustawodawczej, odbytego w dniu 28 maja 1942 roku, AAN 2/133/0/6/45, k. 1.

83 Ibidem.

${ }^{84}$ Ibidem, k. 2.

85 Ibidem. 
paragrafy, w tym o przepis regulujący zasady wniesienia kasacji od wyroku sądu apelacyjnego orzekającego w pierwszej instancji ${ }^{86}$.

Projekt przyjęty przez Sekcję Techniki Ustawodawczej KPU został następnie przedłożony pod dyskusję podczas specjalnego posiedzenia plenarnego Komisji Prac Ustawodawczych w dniach 29 maja i 3 czerwca 1942 roku $^{87}$. W posiedzeniu uczestniczyli: prof. Wacław Komarnicki, prof. Eugeniusz Jarra, dr Karol Aleksandrowicz, dr Ignacy Baliński, prof. Tadeusz Brzeski, dr Tadeusz Cyprian, Władysław Czapiński, prof. Stefan Glaser, prof. Bronisław Hełczyński, prof. Marian Jedlicki, dr Ludwik Krajewski, dr Roman Kuratowski, Prezes Konstanty Makomski, radca W. Moderow, prof. Roman Piotrowski, sędzia Piotr Siekanowicz, dr Mieczysław Szerer, płk. mec. Stanisław Szurlej, prof. Bohdan Winiarski ${ }^{88}$, dr Karol Poznański.

Debata nad projektem dekretu „o karaniu za niektóre zbrodnie dokonane w czasie wojny" podczas obrad plenarnych Komisji Prac Ustawodawczych koncentrowała się na trzech zasadniczych problemach: zasadności ogłaszania opracowywanego aktu prawnego w formie dekretu Prezydenta RP, na wydźwięku politycznomiędzynarodowym prowadzonych prac oraz na uwagach merytorycznych do treści poszczególnych przepisów projektu.

Już na początku obrad wniosek o wydanie deklaracji rządowej w przedmiocie celowości i konieczności ,ujęcia projektu w formę dekretu” zgłosił prof. Roman Piotrowski, który gorąco sprzeciwiał się temu rozwiązaniu. W głosowaniu nad wnioskiem prof. Piotrowskiego za ogłoszeniem przygotowywanego aktu prawnego w formie dekretu Prezydenta RP głosowali wszyscy uczestnicy zebrania z wyjątkiem prof. Piotrowskiego oraz dr Stanisława Szurleja, który wstrzymał się od głosu i ,zastrzegł, że wolałby formę deklaracji”" ${ }^{89}$. W jego opinii publikacja dekretu mogłaby osłabić akcję informacyjno-propagandową Ministerstwa Spraw Zagranicznych oraz Ministerstwa Informacji i Dokumentacji, stwarzając wrażenie, ,że już wszystko zrobione w kierunku propagowania idei kary na Niemców, a przecież na tym polu jest wiele do zrobienia i większy to będzie miało skutek niż ustawa" 90 . Brak poparcia ze strony aliantów dla zdecydowanego stanowiska polskiego stanowiło, dodatkowo, zagrożenie dla pozycji Polski na arenie mię-

${ }^{86}$ Ibidem, k. 3: „Art. 9. § 1 Sprawy o przestępstwa objęte dekretem niniejszym należą do właściwości Sądów Apelacyjnych, wyrokujących w pierwszej instancji.

$\S 2$ Sąd Apelacyjny orzeka w składzie 3 sędziów według przepisów o postępowaniu przed sądem okręgowym.

§ 3 Od wyroku Sądu Apelacyjnego strony mogą składać kasację do Sądu Najwyższego.

§ 4 Sąd Najwyższy rozpatruje kasację od wyroku skazującego na karę śmierci najpóźniej w ciągu miesiąca od chwili wpłynięcia aktów sprawy do tego sądu".

87 Protokół posiedzenia plenarnego Komisji Prac Ustawodawczych, odbytego w dniach 29 maja, 2, 3 i 8 czerwca 1942 roku, AAN 2/133/0/6/ 29, k. 8-19.

88 Ibidem, k. 1.

89 Ibidem, k. 9.

90 Ibidem, k. 11. 
dzynarodowej: „Alianci nie przyłączą się do nas z różnych powodów, co wywoła wrażenie, że my jedni jesteśmy żądni zemsty i to krwawej. Ustawa bowiem przeważnie wprowadza karę śmierci"91. Obawy Stanisława Szurleja podzielał Tadeusz Cyprian, który przekonywał, że „w razie jakichkolwiek komplikacji natury dyplomatycznej, należałoby ogłoszenie dekretu odłożyć do czasów powojennych"92. Jednocześnie podkreślał, że najważniejszym argumentem na rzecz wydania tego aktu prawnego są niewystarczające regulacje polskiego kodeksu karnego w zakresie stanów faktycznych i sankcji. Tadeusz Cyprian przyznał, ,że dekret dokonuje w wyłomu w zasadzie nullum crimen sine lege", był jednak zdania, że „W stosunku do Niemców, którzy sami wyjęli się spod prawa, nie należy się tym względem krępować"93.

Na kontekst międzynarodowy toczących się prac zwrócili uwagę także prof. Winiarski i prof. Jedlicki, zgłaszając ministrowi sprawiedliwości w imieniu Komisji Prac Ustawodawczych dwa wnioski określające polskie stanowisko wobec problemu represji karnej zbrodniarzy wojennych. Winiarski przedstawił propozycję wystąpienia „na Radzie Ministrów z wnioskiem o podjęcie wobec tych państw sprzymierzonych, których terytoria nie zostały zajęte przez okupantów, akcji mającej na celu zarządzenie już teraz odwetowego traktowania pozostających w ich mocy poddanych państw nieprzyjacielskich" 94 . Z kolei prof. Jedlicki wnosił o podjęcie przez Radę Ministrów ,inicjatywy w kierunku wydania przez wszystkie państwa sprzymierzone ustaw, względnie dekretów, zapowiadających represje za zbrodnie dokonane przez niemieckich okupantów w pogwałceniu przepisów prawa międzynarodowego" 95 . Wniosek ten przedłożył Radzie Ministrów Wacław Komarnicki 23 czerwca 1942 roku.

Jako pierwszy wniosek dotyczący merytorycznej strony dekretu zgłosił Ignacy Baliński, który poruszył problem podniesiony już wcześniej przez Stanisława Szurleja, a mianowicie uwzględnienia w opracowywanym akcie prawnym zasady odpowiedzialności odszkodowawczej ex delicto. Chodziłoby, jak wskazywał sędzia Baliński, o przepisy „dające osobom poszkodowanym przez czyny przewidziane w art. 1-6, względnie ich spadkobiercom, podstawę do wszczęcia powództwa cywilnego przeciw krzywdzicielom o wynagrodzenie szkód materialnych"96.

91 Ibidem.

92 Ibidem, k. 11.

93 Ibidem, k. 9.

94 W lipcu 1942 roku z podobnym wnioskiem wystąpią wspólnie rządy państw okupowanych we wspólnej nocie przygotowanej przez Inter Allied Commission. Por. Punishment for War Crimes (2) Collective Notes presented to the Governments of Great Britain, the USSR and the USA, Published for the Inter-Allied Information Committee, London 1942.

95 Protokół posiedzenia plenarnego Komisji..., k. 9. Por. także uchwała KPU — wnioski na Radę Ministrów. Wniosek zawierający rezolucję Komisji Prac Ustawodawczych Wacław Komarnicki przedłożył Radzie Ministrów 23 czerwca 1942 roku, AAN 2/133/0/6/44, k. 395.

96 AAN 2/133/0/6/29, k. 9. 
Kolejny punkt dyskusji dotyczył brzmienia art. 1 projektu dekretu („kto wbrew zasadom prawa międzynarodowego działa w Polsce lub zagranicą na szkodę interesu publicznego Państwa Polskiego, interesu polskiej osoby prawnej lub interesu prywatnego obywatela polskiego, ulega karze więzienia") i zakresu obowiązywania aktu prawnego. Doktor Karol Aleksandrowicz wskazywał: „W obecnej stylizacji, jako odnoszącej się nie tylko do okupantów (do władz niemieckich), ale również i do obywateli polskich, może być użyty przeciwko tym ostatnim, co nie jest i nie może być intencją projektodawcy"97. Aleksandrowicz zwracał uwagę, że tysiące polskich obywateli były zatrudnione w niemieckiej administracji, policji czy wymiarze sprawiedliwości i wykonywały rozkazy władz okupacyjnych, oraz podkreślał, że wobec obywateli polskich powinny być stosowane przepisy ogólne polskiego kodeksu karnego ${ }^{98}$. Zmiana brzmienia art. 1 w zakresie odpowiedzialności karnej kolaborantów została jednak wprowadzona podczas kolejnego posiedzenia sekcji V KPU 22 i 23 czerwca, kiedy to odstąpiono od intencji odniesienia przepisów dekretu zarówno do obcokrajowców, jak i obywateli polskich, „,którzy złamali obowiązek wierności wobec Rzeczypospolitej przez współpracę z nieprzyjacielem"99. Jak zaznaczał Wacław Komarnicki, „dekret jest aktem politycznym, wkraczającym w dziedzinę norm prawa międzynarodowego”, a „obywatele polscy współpracujący z nieprzyjacielem będą pociągani do odpowiedzialności na podstawie obowiązujących przepisów prawa karnego materialnego"100. Komarnicki zwrócił tym samym uwagę na rozłączność zakresów pojęcia zbrodni wojennej i zbrodni stanu, pod którą można zakwalifikować „złamanie obowiązku wierności wobec Rzeczypospolitej przez współpracę z nieprzyjacielem" 101 .

$\mathrm{Z}$ redakcją art. 1 projektu dekretu związany był także problem reakcji ze strony ZSRR na wydanie przez rząd polski aktu prawnego, którego przepisy mogłyby znaleźć zastosowanie wobec zbrodni sowieckich. Wprawdzie uważano jakiekolwiek zastrzeżenia Rosjan do treści dekretu o karaniu za niektóre zbrodnie dokonane w czasie wojny za mało prawdopodobne, ponieważ stanowiłyby potencjalne obciążenie strony rosyjskiej, utrzymującej, ,że na terytoriach [przez nią — D.U.] okupowanych żadne okrucieństwa czy akty sprzeczne z prawem międzynarodowym"102 nie zostały popełnione, jednak zdawano sobie sprawę, że

97 Ibidem, k. 10.

98 Ibidem.

99 AAN 2/133/0/44, k. 27. „Dekret niniejszy stosuje się do członków nieprzyjacielskich sił zbrojnych, funkcjonariuszy okupacyjnych, obywateli cywilnych Rzeszy Niemieckiej i jej sprzymierzeńców, a także obywateli polskich, którzy złamali obowiązek wierności wobec Rzeczypospolitej przez współpracę z nieprzyjacielem, i obejmuje czyny popełnione po dniu 31 sierpnia 1939 roku aż do ukończenia wojny bez względu na miejsce popełnienia czynu".

100 Por. Załącznik nr 2 do protokołu posiedzenia Sekcji KPU 22 i 23 czerwca 1942 roku, AAN 2/133/0/44, k. 24.

101 Ibidem.

102 AAN 2/133/0/29, k. 10. 
samo podejrzenie zamiaru ścigania na podstawie opracowywanego dekretu również zbrodniarzy sowieckich znacznie osłabiało szansę na pozytywne przyjęcie tego aktu prawnego na arenie międzynarodowej ${ }^{103}$.

Dalsze uwagi zgłaszane w trakcie posiedzenia plenarnego Komisji Prac Ustawodawczych na przełomie maja i czerwca 1942 roku dotyczyły kolizji przepisów dekretu o karaniu za niektóre zbrodnie popełnione w czasie wojny z przepisami dekretu Prezydenta RP o sądach doraźnych z 19 marca 1928 roku (Dz.U. z 1928 r. $\mathrm{Nr} 33$ poz. 315), propozycji włączenia do opracowywanych przepisów „odpowiedzialności karnej okupantów za niszczenie polskiego mienia kulturalnego"104, ustanowienia kar dodatkowych przepadku majątku i utraty zdolności do dziedziczenia oraz redakcji i uzupełnień konkretnych paragrafów dekretu. Pierwszy z wymienionych problemów podniósł Władysław Czapiński, przypominając, że 1 września 1939 roku wprowadzony został w Polsce stan wojenny i postępowanie doraźne ${ }^{105}$ przewidujące z samej ustawy zaostrzenie kary ciężkiego więzienia do kary śmierci ${ }^{106}$. W opinii Czapińskiego zachodziła obawa, ,iż w pewnej mierze stosowanie przepisów projektowanego dekretu może złagodzić zarówno tryb postępowania, jak i sankcje przewidziane w przepisach o sądownictwie doraźnym"107. Podczas omawianego posiedzenia Komisji Prac Ustawodawczych art. 9 projektu dekretu, określający właściwość sądów powszechnych (sądów apelacyjnych orzekających w I instancji), uzupełniony został jedynie o dodatkowy ustęp stanowiący, że ,postanowienie w sprawach z dekretu niniejszego może odbywać się zaocznie w razie niemożności uzyskania stawiennictwa sprawcy przed sądem"108, jednak pytanie o to, jaki tryb postępowania — postępowanie doraźne, przed sądami wojskowymi czy sądami karnymi powszechnymi — powinien zostać wprowadzony w sprawach o zbrodnie wojenne, było przedmiotem żywej dyskusji aż do ostatniego etapu prac nad tekstem dekretu. Podczas obrad 3 czerwca 1942 roku obecni na posiedzeniu członkowie Komisji Prac Ustawodawczych jednogłośnie przyjęli natomiast zgłoszoną przez sędziego Ignacego Balińskiego propozycję uzupełnienia przepisów dekretu o przestępstwo „zniszczenia mienia

103 Dyskusję nad tą kwestią zakończono podczas plenarnego posiedzenia Rady Ministrów 2 lipca 1942 roku, które gen. Władysław Sikorski podsumował stwierdzeniem: „dekret w ostatecznej wersji musi mieć wydźwięk antyniemiecki”.

104 AAN 2/133/0/29, k. 12.

105 Zarządzenie Prezydenta Rzeczypospolitej z dnia 1 września 1939 roku o stanie wojennym, Dz.U. z 1939 r. Nr 86, poz. 544; Rozporządzenie Rady Ministrów z dnia 1 września 1939 roku o wprowadzeniu postępowania doraźnego przed sądami powszechnymi w sprawach o niektóre przestępstwa, Dz.U. 1939 r. Nr 87, poz. 554.

106 Art. 32 Dekretu Prezydenta o postępowaniu doraźnym (Dz.U. z 1928 r. Nr 33, poz. 315) stanowił: „Jeżeli oskarżony zostanie uznany przez sąd jednomyślnie winnym, natenczas za przestępstwo, które w postępowaniu zwyczajnym zagrożone jest co najmniej karą ciężkiego więzienia, należy wymierzyć w postępowaniu doraźnym karę śmierci”.

107 AAN 2/133/0/29, k. 12.

108 Ibidem, k. 14. 
kulturalnego, np. pomnika, czego jednak nie można uznać za szkodę Państwa"109. Po dyskusji nad wnioskiem Igancego Balińskiego, w której uczestniczyli Stefan Glaser, Roman Piotrowski, Bronisław Hełczyński, dr Roman Kuratowski, Stanisław Szurlej i Wacław Komarnicki, plenum KPU jednomyślnie uchwaliło treść nowego art. 6 dekretu: „Kto wbrew normom prawa międzynarodowego niszczy polskie mienie kulturalne, podlega karze dożywotniego więzienia lub karze śmierci" ${ }^{\prime 10}$. Ponadto wprowadzono zmiany do treści art. 4, 5 i 7 projektu dekretu. $\mathrm{W}$ art. 4 poszerzeniu uległ zakres kar przewidzianych za zmuszenie obywatela polskiego do wstąpienia do armii nieprzyjaciela lub do świadczenia pracy przymusowej od kary dożywotniego pozbawienia wolności do kary śmierci. Artykuł 5 stanowił: „§ 1 Kto w Polsce lub zagranicą orzekając w imieniu władz okupacyjnych na podstawie przepisów prawnych, wydanych wbrew normom prawa międzynarodowego, wyrządza krzywdę obywatelowi polskiemu, podlega karze więzienia. § 2 Jeżeli tego rodzaju orzeczenie spowodowało jeden ze skutków wymienionych w art. 2 lub 3, sprawca podlega karze dożywotniego więzienia lub karze śmierci" 111 . Artykuł 7 projektu ustanawiał zaś kary dodatkowe przepadku majątku i utraty zdolności do dziedziczenia. Artykuły od 10 do 13 przyjęto większością głosów bez zmian w stosunku do wersji pierwotnej.

Atmosferę dyskusji dobitnie oddają uwagi Tadeusza Cypriana i ministra Komarnickiego, przedstawione po głosowaniu nad tekstem dekretu 2 czerwca 1942 roku. „Głosując za ustawą - zaznaczał Tadeusz Cyprian — podkreślam, że do chwili możliwości wprowadzenia jej w życie jest ona wyłącznie aktem politycznym i jako taka musi być traktowana. Ponadto z uwagi na podważenie zasadniczych pojęć prawnych jest ona tematem bardzo niebezpiecznym, gdyż może poderwać zaufanie społeczeństw zachodnich do naszego poczucia praworządności"112. Przed ogłoszeniem ustawy, a nawet przed wydaniem komunikatu o planach jej ogłoszenia, należało w ocenie Tadeusza Cypriana zasięgnąć opinii aliantów i przedstawić jej tekst Brytyjczykom oraz „wysondować ich opinię w stosunku do zagadnienia tak pod kątem politycznym, jak i prawnym" 113 . W przypadku negatywnej reakcji na polski projekt za konieczne uważał zachowanie projektu dekretu w tajemnicy ${ }^{114}$. Do zastrzeżeń Tadeusza Cypriana odniósł się w swoim przemówieniu, zamykającym część posiedzenia poświęconą projektowi dekretu „o karaniu za niektóre przestępstwa popełnione w czasie wojny”, Wacław Komarnicki, podkreślając, że zdaje sobie sprawę z zastrzeżeń związanych z zamiarem nadania dekretowi wstecznej mocy obowiązywania. „Cyniczne podeptanie przez Niemców wszelkich zasad prawych i moralnych” stwarzało w opinii

\footnotetext{
109 Ibidem, k. 12.

110 Ibidem, k. 10.

111 Ibidem.

112 Ibidem, k. 14.

113 Ibidem.

114 Ibidem.
} 
ministra sprawiedliwości podstawę zastosowania do tych czynów nadzwyczajnego środka, jakim miała być projektowana ustawa. W opinii Komarnickiego wydanie dekretu byłoby ,jak najlepiej przyjęte przez Kraj i dałoby mu podtrzymanie moralne, z drugiej zaś strony mogłoby wpłynąć w pewnym stopniu hamująco na oprawców niemieckich”. Ponadto, konkludował minister sprawiedliwości, „wyjątkowa sytuacja Polski byłaby przez wydanie tego dekretu szczególnie zaakcentowana"115.

W dniach 22 i 23 czerwca miały miejsce posiedzenia specjalne Sekcji V Prawa i Postępowania Karnego i Więziennictwa Komisji Prac Ustawodawczych, podczas których przedyskutowano dalsze poprawki do tekstu ,dekretu Prezydenta RP o karaniu za niektóre zbrodnie dokonane w czasie wojny"116. Jak już nadmieniono, zmieniona została treść art. 1 projektu dekretu, określającego zakres jego obowiązywania co do miejsca i osób. Oprócz skreślenia ustępu odnoszącego się do obywateli polskich na wniosek Stanisława Szurleja do art. 1 włączono zasadę odpowiedzialności podżegaczy i pomocników, wskutek czego przyjął on brzmienie: „Dekret niniejszy stosuje się do członków nieprzyjacielskich sił zbrojnych, funkcjonariuszy okupacyjnych, obywateli cywilnych Rzeszy Niemieckiej i jej sprzymierzeńców oraz ich podżegaczy i pomocników i obejmuje czyny popełnione po dniu 31 sierpnia 1939 roku aż do ukończenia wojny bez względu na miejsce popełnienia czynu"117. Przyjęto także nowy tytuł projektowanego aktu prawnego: „Dekret Prezydenta RP o karaniu za zbrodnie wojenne”. Skreślony został art. 9 ustanawiający w sprawach o popełnienie zbrodni wojennych właściwość sądów karnych powszechnych, w miejsce których za właściwe uznano sądy wojenne, co w opinii Wacława Komarnickiego odpowiadało ,prawu międzynarodowemu i dotychczasowej praktyce państw” oraz dawało gwarancję skutecznego wymiaru sprawiedliwości dla zbrodniarzy ${ }^{118}$. W nowym brzmieniu art. 10 stanowił, iż „sprawy o przestępstwa objęte dekretem niniejszym podlegają właściwości sądów wojennych". W związku z tym skreślono art. 11 ustanawiający początek biegu terminów na moment wznowienia prac Sądu Najwyższego oraz w art. 12 projektu dekretu powierzono wykonanie jego przepisów Ministrowi Sprawiedliwości i Ministrowi Spraw Wojskowych. Artykuł 13 pozostawiono bez zmian.

Uchwalony 23 czerwca przez Komisję Prac Ustawodawczych tekst projektu dekretu, jego pierwotną wersję oraz uzasadnienie minister Komarnicki przesłał tego samego dnia do pozostałych ministerstw rządu londyńskiego z prośbą o nadesłanie uwag do treści dokumentu w terminie trzech dni ${ }^{119}$. W imieniu Pre-

115 AAN 2/133/0/6/29, k. 16.

116 W. Komarnicki, Uwagi dodatkowe do uzasadnienia projektu dekretu Prezydenta RP „o karaniu za zbrodnie wojenne”, AAN 2/133/0/6/44, k. 23-29. Wniosek Komarnickiego, zawierający proponowane cztery poprawki - k. 27.

117 Ibidem, k. 25.

118 Ibidem, k. 422.

119 Pismo Komarnickiego zostało przesłane według rozdzielnika Prezydium Rady Ministrów, Ministerstwu Spraw Wewnętrznych, Ministerstwu Spraw Zagranicznych, Ministerstwu Spraw 
zydium Rady Ministrów na pismo Komarnickiego już 24 czerwca opowiedział Dyrektor Biura Prezydialnego Adam Romer ${ }^{120}$. Prezydium Rady Ministrów krytycznie odniosło się do zmiany trybu postępowania wprowadzonej w nowym art. 10 projektu i opowiadało się za utrzymaniem właściwości sądów powszechnych, wskazując na kolizję przepisów prawa o ustroju sądów wojskowych z założeniami ścigania i karania zbrodniarzy wojennych. Jak podkreślał Adam Romer, ściganie przestępców wojennych mogłoby nastąpić dopiero po zakończeniu działań wojennych, w myśl zaś art. $8 \S 2$ prawa o ustroju sądów wojskowych sądy te sprawują wymiar sprawiedliwości „w wojsku i marynarce wojennej w czasie wojny"121. Dalsze obiekcje dotyczyły prawomocności wyroków sądów wojennych orzekających karę śmierci, która stanowiła najwyższy wymiar kary w większości przepisów projektu dekretu Prezydenta. W myśl art. 424 kodeksu wojskowego postępowania karnego ${ }^{122}$ wyrok sądu wojennego orzekający karę śmierci stawał się prawomocny po zatwierdzeniu go przez Naczelnego Wodza, a w „obszarze warownym lub rejonie umocnionym, zamkniętym przez nieprzyjaciela" ${ }^{23}$ po zatwierdzeniu wyroku przez najwyższego dowódcę tego obszaru. W przypadku wydania wyroku skazującego na karę śmierci w okresie powojennym, ze względu na brak Naczelnego Wodza, wyrok taki nigdy by się nie uprawomocnił. Kolejne trudności wiązały się z treścią art. 410 k.w.p.k., w myśl którego „w postępowaniu przed sądami wojennymi uprawnienia służące w toku śledztwa wojskowemu prokuratorowi okręgowemu" 124 przysługiwały zwierzchnikowi sądowokarnemu. To on rozstrzygał, czy akt oskarżenia może być wniesiony przed sąd wojenny (art. 414). Zwierzchnikiem sądowokarnym w sprawach należących do właściwości sądów wojennych był zaś dowódca jednostki, przy której sąd wojenny został utworzony, lub komendant obszaru, dla którego sąd wojenny został utworzony. Adam Romer wskazywał: „Jest rzeczą wątpliwą, czy tego rodzaju oskarżyciel publiczny będzie posiadał dostateczne kwalifikacje do oceny, czy czyn, będący przedmiotem postępowania, jest sprzeczny z normami prawa międzynarodowego"125.

Uwagom do projektu dekretu zgłoszonym ze strony Prezydium Rady Ministrów i spornej kwestii trybu postępowania w sprawach o zbrodnie wojenne poświęcono specjalne posiedzenie plenarne Komisji Prac Ustawodawczych 29 i 30

\footnotetext{
Wojskowych, Ministerstwu Informacji i Dokumentacji, Ministerstwu Pracy i Opieki Społecznej, Ministerstwu Skarbu, Ministerstwu Przemysłu i Handlu oraz do Biura Prac Administracyjnych, Biura Prac Ekonomicznych, Politycznych i Prawnych, do Urzędu Oświaty i Spraw Szkolnych i Kancelarii Cywilnej Prezydenta RP — IPMS, Kol. S. Strońskiego, 180/3, strony niepaginowane.

120 Pismo Dyrektora Biura Prezydialnego, Adama Romera, do Komarnickiego „w odpowiedzi na pismo z dnia 23 czerwca 1942 roku, Nr 1024/42 w sprawie projektu dekretu o karaniu za zbrodnie wojenne", odpis: AAN 2/133/0/6/44, k. 21-22.

121 Dz.U. z 1936 r. Nr 76, poz. 537.

122 Ibidem.

123 Ibidem.

124 Ibidem.

125 AAN 2/133/0/6/44, k. 22.
} 
czerwca 1942 roku, w którym uczestniczyli: Wacław Komarnicki, Eugeniusz Jarra, Stefan Glaser, Roman Piotrowski, Stanisław Szurlej, Mieczysław Szerer, Ludwik Krajewski i Tadeusz Cyprian. Zmiany sugerowane w piśmie z 24 czerwca przez Adama Romera popierał Ludwik Krajewski, który podczas omawianego posiedzenia Komisji Prac Ustawodawczych wnioskował skreślenie art. $10 \mathrm{w}$ dotychczasowym brzmieniu i określenie właściwości sądów powszechnych lub ,gdyby to nie było możliwe - sądów doraźnych" ${ }^{26}$. Stanowisko to poparli Tadeusz Cyprian i Roman Piotrowski proponujący uchwalenie art. $10 \mathrm{w}$ brzmieniu: „Sprawy o przestępstwa objęte dekretem niniejszym podlegają właściwości sądów powszechnych, orzekających w trybie postępowania doraźnego"127. Wprowadzaniu postępowania doraźnego stanowczo sprzeciwiał się Stanisław Szurlej, który proponował przyjęcie w art. 10 właściwości sądów wojennych podlegających właściwości sądów wojskowych, orzekających w trybie postępowania wojennego ${ }^{128}$. Podczas głosowania nad obiema propozycjami członkowie KPU przegłosowali treść art. $10 \mathrm{w}$ brzmieniu zaproponowanym przez Stanisława Szurleja ${ }^{129}$, odrzucając tym samym zastrzeżenia zgłoszone przez Prezydium Rady Ministrów. Drugim punktem dyskusji podczas posiedzenia KPU była treść art. 1 projektu dekretu. Tadeusz Cyprian wnosił o utrzymanie pierwotnego brzmienia art. 1: „Kto wbrew normom prawa międzynarodowego dopuszcza się w Polsce lub zagranicą czynu, na szkodę Państwa Polskiego, polskiej osoby prawnej lub obywatela polskiego podlega karze więzienia"130. Natomiast Roman Piotrowski i Stanisław Szurlej opowiadali się za usunięciem z treści art. 1 fragmentu dotyczącego podżegaczy i pomocników. Przyjęcie 30 czerwca 1942 roku przez Komisję Prac Ustawodawczych propozycji Tadeusza Cypriana i usunięcie z projektu dekretu ustępu określającego precyzyjnie adresatów tego aktu prawnego (,,członków nieprzyjacielskich sił zbrojnych, funkcjonariuszy okupacyjnych, obywateli cywilnych Rzeszy Niemieckiej i jej sprzymierzeńców oraz ich podżegaczy i pomocników”) stało się jedną z przyczyn zdjęcia z porządku obrad najbliższego posiedzenia Rady Ministrów głosowania nad przyjęciem tekstu dekretu Prezydenta RP o karaniu za zbrodnie wojenne.

\section{Debata nad tekstem dekretu podczas posiedzeń plenarnych Rady Ministrów. Lipiec-październik 1942 roku}

Projekt dekretu Prezydenta RP o karaniu za zbrodnie wojenne został po raz pierwszy zaprezentowany przez ministra Komarnickiego na posiedzeniem

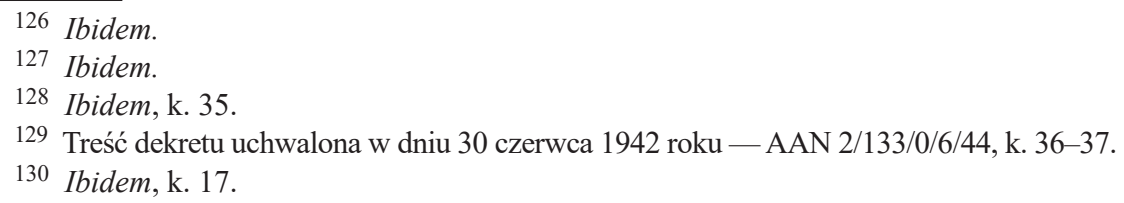


plenarnym Rady Ministrów 2 lipca 1942 roku. Podczas obrad na problem związany z interpretacją zmienionego kilkukrotnie art. 1 projektu dekretu zwrócił uwagę kierujący Ministerstwem Informacji i Dokumentacji, odpowiedzialny również za promowanie postulatu rządu polskiego ukarania nazistowskich zbrodniarzy wojennych w mediach międzynarodowych, prof. Stanisław Stroński. Jak zaznaczał, pierwotna treść art. 1 miała „ostrze wyłącznie przeciwniemieckie, natomiast ostatnia przez opuszczenie art. 1 ma ostrze zwrócone przeciw wszystkim okupantom, a więc i przeciwko Rosji, co politycznie pozbawia projekt wszelkich widoków realnych"131. Opinię tę podzielał premier Sikorski, podkreślając, że „dekret w ostatecznej wersji musi mieć wydźwięk antyniemiecki”132. Planowana na 2 lipca dyskusja nad projektem została przełożona na kolejne posiedzenie Rady Ministrów, do czasu którego premier Sikorski zobowiązał ministra sprawiedliwości do ponownego rozpatrzenia zgłoszonych dotychczas uwag do tekstu dekretu.

Na przełomie czerwca i lipca 1942 roku zastrzeżenia do przebiegu prac nad omawianym aktem prawnym z punktu widzenia Ministerstwa Spraw Zagranicznych opracował Michał Potulicki. Krytycznie oceniał on zaprzestanie przez ministerstwo sprawiedliwości organizacji zapoczątkowanych w kwietniu 1942 roku prac konferencji międzyministerialnych i opracowanie projektu tekstu dekretu w wąskim gronie pracowników resortu sprawiedliwości i Komisji Prac Ustawodawczych bez konsultacji z Ministerstwem Spraw Zagranicznych. Jak zaznaczał polski dyplomata, „tego rodzaju projekty prawa międzynarodowego nie powinny wychodzić na szersze forum bez Ministerstwa Spraw Zagranicznych, [...] tym bardziej, że Ministerstwo to zajmuje się zagadnieniem karania Niemców w płaszczyźnie międzyalianckiej"133. W opinii Potulickiego zasadniczym punktem odniesienia dla rządu polskiego $\mathrm{w}$ omawianej dziedzinie powinno być stanowisko wypracowane w ramach utworzonej przez sygnatariuszy deklaracji z St. James's Komisji Międzyalianckiej do spraw Karania Zbrodni Wojennych (Inter-Allied Commission on the Punishment of War Crimes), której członkowie ,jak dotąd [...] wypowiadają się silnie przeciw faszystowsko-nazistowskiemu systemowi wstecznego karania" ${ }^{34}$. W centrum prac komisji w czerwcu 1942 roku znajdowało się opracowywanie warunków zawarcia rozejmu z Rzeszą Niemiecką, kwestia sporządzenia umów ekstradycyjnych oraz ustalenie rodzaju sądów i trybu postępowania właściwych w sprawach krajowych o zbrodnie wojenne. Jak zaznaczał radca prawny polskiego MSZ, ,,wszystkie te sprawy projekt dekretu albo przesądza jednostronnie, albo częściowo przekreśla, wpędzając nas w izolowaną

131 Protokół posiedzenia Rady Ministrów z dnia 2 lipca 1942 roku, IPMS, PRM-K, 102/48a, k. 2-5, Protokoty..., t. 4, s. 352-353.

132 Ibidem.

133 Notatka dla Pana Ministra z 18 czerwca 1942 roku, załącznik do protokołu IPMS, PRM-K. 102/48c, k. 40-41 - Protokoty..., t. 4, s. 372-373.

134 Notatka Michała Potulickiego dla premiera i ministra sprawiedliwości z 30 czerwca 1942 roku, IPMS, PRM-K. 102/ 48 c, k. 25-27 - Protokoty..., t. 4, s. 370-372, tu: s. 371. 
pozycję dla błahej [...] nadziei, że rozplakatowanie dekretu w okupowanej Polsce wstrzyma Niemców od dalszych prześladowań" ${ }^{135}$. Z nadaniem dekretowi wstecznej mocy obowiązywania Potulicki wiązał niebezpieczeństwo natury polityczno-propagandowej uczynienia z rządu polskiego „ukrytych ideologów faszyzmu"136. Co warte podkreślenia, główną przyczyną sceptycyzmu Potulickiego wobec koncepcji dekretu była jego recepcja na forum międzynarodowym i brak poparcia ze strony Wielkiej Brytanii i USA dla idei represji karnej zbrodniarzy wojennych. W swojej notatce dla Edwarda Raczyńskiego przyznał: „Rozumiem, że może nadejść czas, po zakończeniu wojny, kiedy i tak będziemy mogli wprowadzić zasady wsteczności działania ustaw karnych w stosunku do okupantów, ale na to jeszcze mamy czas"137. Wobec braku realnych możliwości wykonania przepisów dekretu przed zakończeniem wojny opowiadał się za ogłoszeniem w Polsce odezwy wyrażającej główne założenia dekretu, która jednak „nie wiązałaby rąk Pana Premiera na forum alianckim i nie zawierałaby zbyt precyzyjnych formuł prawnych" 138 .

Odpowiedzią Wacława Komarnickiego na krytyczne uwagi zgłaszane $\mathrm{w}$ trakcie opracowywania projektu dekretu o karaniu za zbrodnie wojenne były krótkie opracowania prezentowane przez ministra sprawiedliwości w formie referatów podczas posiedzeń plenarnych Rady Ministrów 2 i 15 lipca oraz 17 października 1942 roku, a wcześniej Komisji Prac Ustawodawczych 23 czerwca 1942 roku. Kluczowym argumentem przemawiającym za ogłoszeniem dekretu Prezydenta RP o karaniu za zbrodnie wojenne był brak przepisów prawa krajowego i międzynarodowego, zawierających stany faktyczne i sankcje mogące znaleźć zastosowanie do zbrodni niemieckich popełnianych w ramach „systemu

135 Ibidem.

136 Ibidem.

137 IPMS, PRM-K. 102/48c, k. 40-41.

138 Ibidem, s. 371. W tym samym tonie argumentuje Piotrowski: „Byłoby [...] rzeczą wysoce niebezpieczną i niewskazaną plamić własne ustawodawstwo za wzorem niemieckiego przez wprowadzenie do niego chociażby tylko »tytułem retorsji« zasad, będących zaprzeczeniem najprymitywniejszego poczucia sprawiedliwości i praworządności; zasad, które oderwałyby ustawodawstwo polskie od rodziny ustawodawstw — państw cywilizowanych, sprowadzając je na jeden moralny poziom z prawodawstwem hitlerowskich Niemiec [...].

Wydanie takiego dekretu wywołałoby zrozumiałe zgorszenie nawet wśród naszych przyjaciół w państwach sprzymierzonych, zwłaszcza anglosaskich (W. Brytania i USA), w których poczucie prawne i poszanowanie prawa są szczególnie wysoko rozwinięte. Zrodziłoby to także wśród nich usprawiedliwione wątpliwości co do wyjątkowej karygodności zbrodni niemieckich oraz co do słuszności zapewnienia ekstradycji ich sprawców sądom krajowym poszkodowanych państw.

Zachwialibyśmy niewątpliwie ich wiarę w zdolność bezstronnego sprawiedliwego osądzenia zbrodni niemieckich w szczególności przez polskie sądy, skoro Polska potrafiła tak bezceremonialnie dla celów wyłącznie politycznych, nie prawnych, podeptać oficjalnie, w akcie ustawodawczym, najbardziej fundamentalne zasady wymiaru sprawiedliwości, z pogwałceniem na dobitkę własnej Konstytucji” - Uwagi do projektu Dekretu Prezydenta RP o karaniu za zbrodnie wojenne przesłane 1 lipca 1942 roku na ręce Ministra Sprawiedliwości w związku z posiedzeniem Rady Ministrów w dniu 2 lipca 1942 roku, AAN 2/133/0/6/44, k. 458-465, tu: k. 459, 462. 
wojny totalnej” i okrucieństw zadawanych ,z takim wyrafinowaniem i w takich rozmiarach, jakich nie spotykamy w żadnej z wojen współczesnych" ${ }^{139}$. Oprócz braku precyzyjnego ujęcia stanów faktycznych w istniejących przepisach prawa krajowego i międzynarodowego zastosowanie tych przepisów w sprawach o zbrodnie wojenne było w ocenie Komarnickiego niewskazane ze względu na niewspółmierność przewidzianych w nich kar do wagi popełnionych przestępstw. „Nasilenie zbrodniczości, wyrafinowanie przestępcze, jakie wykazali Niemcy, jest tak wielkie, że również i przewidziane w Konwencjach i Kodeksach kary rażą swą nieproporcjonalnością"140. Jak zaznaczał Komarnicki, szczególna sytuacja Polski, wynikająca ze skali popełnianych na jej terenach zbrodni oraz ich cel — „zniszczenie narodu polskiego, odebranie mu zarówno materialnych podstaw jego istnienia, jak i zniszczenie przez wieki nagromadzonego dorobku kulturalnego" - dodatkowo legitymizowały władze polskie do zastosowania wszelkich dostępnych środków powstrzymania niemieckiej polityki eksterminacji i określenia zasad karania sprawców zbrodni wojennych. Dlatego ogromną wagę Komarnicki przywiązywał do formy, w jakiej zamiar pociągnięcia zbrodniarzy wojennych do indywidualnej odpowiedzialności karnej przez rząd polski miał zostać ogłoszony i przekonywał, że ,ze względu [...] na to, że powaga aktu ustawodawczego, jakim jest dekret Prezydenta Rzeczypospolitej oraz jego moc wiążąca są najwyższe — tej formy należy użyć, jako wyrazu woli Rzeczypospolitej karania sprawców zbrodni niemieckich" 141 .

Zdecydowane stanowisko rządu polskiego, wyrażone w formie ustawy regulującej podstawy prawne odpowiedzialności karnej przestępców wojennych, byłoby z jednej strony odpowiedzią na oczekiwania i wsparciem moralnym ludności okupowanej Polski ${ }^{142}$, z drugiej zaś stanowiłoby sprzeciw wobec ataku na „poczucie prawne narodów kulturalnych" oraz wobec łamania przez Niemcy elementarnych zasad prawa międzynarodowego i stosunków międzynarodowych. Swoje wystąpienie podczas posiedzenia plenarnego Rady Ministrów 2 lipca 1942 roku minister Komarnicki rozpoczął od przywołania cytowanego już fragmentu deklaracji lutowej, w której postulaty surowego ukarania zbrodniarzy wojennych oraz „zupełnego i skutecznego, wykluczającego na przyszłość agresję rozbrojenia” Niemiec zostały włączone do oficjalnego programu rządu polskiego na emigracji, zaś ich realizację uznano za „nakaz elementarnej sprawiedliwości dziejowej”143. Tym samym, argumentował kierownik resortu sprawiedliwości, rząd polski ,postawił

139 AAN 2/133/0/6/44, k. 409.

140 Ibidem, k. 469.

141 Ibidem, k. 410.

142 Stosunek społeczeństwa polskiego wobec okupantów i koncepcje odwetu na Niemcach w oparciu o artykuły prasowe publikowane na łamach „Biuletynu Informacyjnego” omawia A. Basak, Kwestia ukarania zbrodni niemieckich na łamach „Biuletynu Informacyjnego” Armii Krajowej 1940-1945, „Acta Universitatis Wratislaviensis No 543. Historia” 36, 1981, s. 59-84.

143 Referat Ministra Sprawiedliwości o projekcie dekretu o karaniu za zbrodnie wojenne, wygłoszony na posiedzeniu Rady Ministrów w dniu 2 lipca 1942 roku, AAN 2/133/0/44, k. 405. 
sprawę na najwyższym poziomie", nie ograniczając się jedynie do wyrównania doznanych przez Polskę krzywd i przyjął ,stanowisko ogólne, zmierzające do spełnienia nakazu elementarnej sprawiedliwości dziejowej, a więc do zapanowania w stosunkach międzynarodowych zasad moralnych" ${ }^{144}$. Odwołując się w swoich wystąpieniach do aksjologicznych podstaw prawa międzynarodowego, przede wszystkim zasady słuszności i sprawiedliwości, oraz włączając do źródeł prawa międzynarodowego zarówno umowy i konwencje międzynarodowe, jak i prawo zwyczajowe oraz ,poczucie prawne narodów kulturalnych”, Komarnicki proponował rozwiązanie problemu odpowiedzialności karnej za zbrodnie wojenne i braku norm prawa pozytywnego, regulujących jej zasady, przy użyciu argumentacji parwnonaturalnej. Niebezpieczeństwu znalezienia się rządu polskiego na wyizolowanej pozycji, przed którym przestrzegał Michał Potulicki, Wacław Komarnicki przeciwstawiał bycie $\mathrm{w}$ awangardzie zmian i występowanie nie $\mathrm{w}$ ochronie partykularnych interesów polskich, lecz ze stanowiska uniwersalistycznego mającego na celu powstrzymanie ,zbrodniczości niemieckiej, która wypływa z systemu burzącego stosunki międzynarodowe i usiłującego cofnąć wstecz rozwój ludzkości” ${ }^{145}$, oraz wynikającą z „,nakazu sprawiedliwości dziejowej” gwarancję zadośćuczynienia ofiar i ukarania sprawców.

Od samego początku prac nad koncepcją dekretu prezydenckiego o odpowiedzialności karnej za zbrodnie wojenne najwięcej kontrowersji budziło nadanie ustawie wstecznej mocy obowiązywania. Opowiadając się za utrzymaniem mocy obowiązującej ustawy od dnia 31 sierpnia 1939 roku, Wacław Komarnicki podkreślał, że pozostał zwolennikiem zasad demokracji i praworządności, a intencją autorów dekretu nie było naśladowanie ,pryncypiów nazistowskich stosowania wstecznego ustawy karnej"146. Zdaniem ministra sprawiedliwości utrzymanie proponowanej mocy temporalnej obowiązywania dekretu było uzasadnione jako zastosowanie wobec Rzeszy Niemieckiej środków retorsyjnych stanowiących dopuszczaną przez prawo międzynarodowe formę odwetu, polegającą na zastosowaniu przez państwo szkodliwych, lecz zgodnych z prawem działań w odpowiedzi na szkodliwe działania innego państwa ${ }^{147}$. Przemawiało za tym ,podeptanie przez Niemców w stosunku do Państwa Polskiego i jego obywateli wszelkich zasad prawnych i moralnych", w tym poprzez nadanie wstecznej mocy ustaw karnych. Specjalne przepisy karne na ziemiach zajętych przez wojska niemieckie wprowadzało między innymi rozporządzenie z 1 października 1939 roku o ściganiu przestępstw popełnionych przed 1 września 1939 roku na okupowanych przez wojska niemieckie obszarach polskich ${ }^{148}$. Jak zaznaczał Komarnicki, „na

144 Ibidem.

145 Ibidem.

146 Ibidem, k. 406.

147 Z. Cybichowski, Prawo międzynarodowe publiczne i prywatne, Warszawa 1928, s. 298.

148 Verordnung über die Verfolgung der vor dem 1.09.1939 in den von deutschen Truppen besetzten polnischen Gebieten begangenen strafbaren Handlungen y 1.10.1939, Verordnungsblatt 
podstawie tego dekretu Niemcy skazali na śmierć dziesiątki tysięcy obywateli polskich [...], a także objęli nim bez ograniczenia całe 20-lecie istnienia Państwa Polskiego, stosując go np. do powstańców wielkopolskich i górnośląskich"149. Kolejnym argumentem wysuwanym przez Komarnickiego na rzecz nadania dekretowi mocy obowiązującej od 31 sierpnia 1939 roku był fakt, że jako ustawa specjalna doprecyzowywał on czyny uznane za przestępstwa w aktach prawa krajowego lub międzynarodowego. Minister sprawiedliwości przekonywał, że z punktu widzenia prawa materialnego trudno było mówić o retroaktywności ustawy, a jedynie o jej retroaktywności w sensie formalnym ${ }^{150}$. Wreszcie, jak zaznaczał Komarnicki, wydanie ustawy specjalnej określającej zasady odpowiedzialności karnej za zbrodnie wojenne było nieuniknionym etapem procesu rozliczenia się z niemieckimi zbrodniami, który rząd polski zainicjował na arenie międzynarodowej, doprowadzając do podpisania deklaracji z Pałacu św. Jakuba. Odwołując się do prac międzynarodowych komisji prawniczych - Inter-Allied Commission on the Punishment of War Crimes, London International Assembly i Cambridge Commission on Penal Law Reconstruction and Development, w ramach których opracowywano problem powojennej organizacji wymiaru sprawiedliwości dla przestępców wojennych ${ }^{151}$ - Wacław Komarnicki podkreślał, że „konieczność uregulowania ustawodawczego [...] wymiaru sprawiedliwości dla niemieckich okupantów"152 znajduje coraz większe uznanie wśród prawników brytyjskich. Wdrożenie rozwijanej już w połowie 1942 roku, między innymi w London International Assembly, koncepcji podziału jurysdykcji w sprawach o zbrodnie wojenne pomiędzy sądy krajowe właściwe do sądzenia ogółu przestępców i trybunały międzynarodowe dla głównych zbrodniarzy nie było możliwe bez uchwalenia ustaw specjalnych określających materialne zasady odpowiedzialności karnej przestępców wojennych. W obu wypadkach konieczne byłoby zastosowanie prawa o wstecznej mocy obowiązywania. Wyjątkowość sytuacji, konkludował Komarnicki, usprawiedliwiała jednak wyjątkowość stosowanego środka ${ }^{153}$. Przekonując, że ogłoszenie dekretu Prezydenta RP o karaniu za zbrodnie wojenne będzie stanowić naturalną kontynuację polskich starań w dziedzinie popularyzacji koncepcji represji karnej zbrodniarzy wojennych, minister sprawiedliwości wskazywał, że polski projekt, jako pierwsza próba kodyfikacji krajowej prawa karnego międzynarodowego, miałby „,duże znaczenie dla ogólnego rozwoju pojęć w tej materii" ${ }^{254}$. Jednak zasadniczym argumentem na rzecz jak

für die besetzte Gebiete in Polen, Nr 24. Zob. K.M. Pospieszalski, Polska pod niemieckim prawem 1939-1945 (Ziemie Zachodnie), s. 136-139 i 266; A. Wrzyszcz, op. cit., s. 57-58.

149 AAN 2/133/0/6/44, k. 471.

150 Ibidem, k. 406.

151 Ibidem, k. 469.

152 Ibidem.

153 Ibidem.

154 Ibidem, k. 470. 
najszybszego ogłoszenia dekretu był jego spodziewany skutek prewencyjny, zatrzymanie eksterminacyjnej polityki niemieckiej oraz podtrzymanie ludności polskiej „w jej nieugiętej postawie wobec okupantów" ${ }^{155}$. Jak podkreślał Komarnicki w zakończeniu swojego referatu wygłoszonego na posiedzeniu plenarnym Rady Ministrów 15 lipca 1942 roku, udzielenie odpowiedzi na pytanie o najwłaściwszy moment dla ogłoszenia dekretu przekraczało jego kompetencje i w tej dziedzinie oddał głos ministrowi spraw wewnętrznych i Prezesowi Rady Ministrów.

Rozbieżność zdań ministra Mikołajczyka opowiadającego się za jak najszybszą publikacją dekretu i premiera Sikorskiego przestrzegającego przed możliwym nasileniem prześladowań i przypominającego, że „najważniejszym naszym celem $\mathrm{w}$ tej sprawie jest i pozostanie zagwarantowanie przez Wielką Brytanię i USA ekstradycji zbrodniarzy niemieckich"156, znalazła odzwierciedlenie podczas głosowania nad uchwaleniem tekstu dekretu podczas posiedzenia plenarnego Rady Ministrów 15 lipca. Za przyjęciem dekretu głosowali ministrowie Mikołajczyk i Kwapiński, przeciw - Seyda i Stańczyk, a minister Raczyński zgłosił zastrzeżenia wynikające z sytuacji międzynarodowej Polski. Uchwalony został natomiast „wniosek kompromisowy” zgłoszony przez Stanisława Strońskiego proponującego przyjęcie przez Radę Ministrów zasad projektu ustawy o odpowiedzialności karnej osób przynależących do Rzeszy Niemieckiej bądź do państw z nią sprzymierzonych za przestępstwa dokonane przed 31 sierpnia 1939 roku oraz upoważnienie ministrów Raczyńskiego, Mikołajczyka i Komarnickiego do przeprowadzenia konsultacji w sprawie ogłoszenia dekretu z rządami państw sprzymierzonych. Ostateczny tekst projektu dekretu o odpowiedzialności karnej za zbrodnie wojenne miał zostać opracowany przez specjalnie powołaną komisję pod przewodnictwem Ministra Sprawiedliwości, w skład której mieli wejść ministrowie Mikołajczyk, Stroński, Seyda i Raczyński. Obrady tej komisji odbyły się w Ministerstwie Sprawiedliwości 8 października 1942 roku ${ }^{157}$.

Podczas posiedzenia dyskusji poddano poprawki do tekstu, zgłoszone przez Stanisława Mikołajczyka i Mariana Seydę, dotyczące art. 1, 3 i 7 projektu dekretu. Proponowana przez Seydę zmiana treści art. 1 dotyczyła rozszerzenia zakresu podmiotowego obowiązywania ustawy i zakładała objęcie odpowiedzialnością karną „Z uwzględnieniem obecnego ustawodawstwa niemieckiego obywateli Rzeszy Niemieckiej oraz osoby posiadające w innej postaci niemiecką przynależność państwową” oraz osoby „przynależne do państw z Rzeszą Niemiecką

155 Ibidem, k. 409.

156 Protokół posiedzenia Rady Ministrów z 15 lipca 1942 roku, IPMS, PRM-K. 102/ 48 c, k. 17-21 , Protokoty..., t. 4, s. 364-365.

157 Protokół Konferencji Ministrów dla ustalenia definitywnego tekstu projektu Dekretu o odpowiedzialności karnej za zbrodnie wojenne, odbytej w Ministerstwie Sprawiedliwości w dniu 8 października 1942 roku o godz. 3. Min. 30, IPMS, Kol. 180/30, strony niepaginowane. 
sprzymierzonych"158. W odniesieniu do art. 3 projektu dekretu obaj ministrowie sugerowali skrócenie terminu pozbawienia wolności przewidzianego $\mathrm{w}$ tym przepisie („Jeżeli czyn wymieniony w art. 2 spowodował śmierć, szczególne udręczenie, kalectwo, trwałą chorobę fizyczną lub psychiczną, pozbawienie wolności na przeciąg co najmniej jednego miesiąca, wysiedlenie lub przesiedlenie obywatela polskiego, sprawca podlega karze dożywotniego więzienia lub karze śmierci”) z miesiąca do 14 dni, tak aby ,przepis ten zrównać z ustawodawstwem polskim" 159 . Kolejne uwagi dotyczyły redakcji art. 7 penalizującego niszczenie i grabież dóbr kultury. W opinii Seydy sformułowania „dobra kultury” czy „mienie o wartości zabytkowej” zawężały zakres obowiązywania normy, a więc i zastosowania dekretu. Sugerował on sankcjonowanie „wypadków rabunku, kradzieży, zniszczenia lub istotnego uszkodzenia mienia publicznego lub prywatnego, jeżeli mienie to stanowi wartość ogólno-narodową" ${ }^{160}$, przez co należało rozumieć mienie zarówno gospodarcze, jak i kulturalne. Mikołajczyk proponował zaś przyjęcie art. $7 \mathrm{w}$ brzmieniu: „Kto wbrew normom prawa międzynarodowego przywłaszcza, uszkadza, niszczy lub wywozi zagranicę mienie mające szczególną wartość dla kultury polskiej, podlega karze dożywotniego więzienia lub karze śmierci" ${ }^{161}$. Po dyskusji nad zgłoszonymi poprawkami przyjęto propozycję skrócenia terminu przewidzianego w art. 3 projektu dekretu oraz następujące brzmienie art. 1 i 7: art. 1 - „Odpowiedzialności karnej z mocy przepisów dekretu niniejszego podlegają osoby przynależne do Rzeszy Niemieckiej lub państw z nią sprzymierzonych lub związanych, bądź pozostające w służbie Rzeszy Niemieckiej, bądź tych państw w czasie wojny, za przestępstwa popełnione po dniu 31 sierpnia 1939 roku, bez względu na miejsce popełnienia czynu”; art. 7 - „Kto wbrew normom prawa międzynarodowego dokonywa rabunku, kradzieży, zniszczenia lub istotnego uszkodzenia mienia publicznego lub prywatnego, jeżeli mienie to stanowi wartość ogólnonarodową, podlega karze dożywotniego więzienia lub karze śmierci"162. Ponadto zmieniono art. 12 określający kompetencje wykonywania dekretu: „Wykonanie dekretu niniejszego porucza się Ministrom Spraw Wewnętrznych, Sprawiedliwości i Spraw Wojskowych" ${ }^{163}$. Pozostałe artykuły zostały bez zmian i w takim brzmieniu, jednak pod nowym tytułem — projekt dekretu Prezydenta RP o odpowiedzialności karnej za zbrodnie wojenne — przedłożono pod obrady Rady Ministrów.

158 Poprawki do tekstu dekretu o odpowiedzialności karnej za zbrodnie wojenne, IPMS, Kol. 180/30, strony niepaginowane.

159 Ibidem. W tym przypadku mowa o art. 5 ustawy z 23 czerwca 1939 roku o stanie wojennym (Dz.U. RP z 1939 r. Nr 57, poz. 366) oraz art. 24 ust. 6 przepisów wprowadzających Kodeksu karnego i prawo o wykroczeniach (Dz.U. RP z 1932 r. Nr 60, poz. 573) oraz o art. 248 § 2 Kodeksu karnego (Dz.U. RP z 1932 r. Nr 60, poz. 571).

160 Ibidem.

161 Ibidem.

162 Ibidem.

163 Ibidem. 
Jedyną zmianą w tekście, zaproponowaną przez Wacława Komarnickiego podczas posiedzenia plenarnego Rady Ministrów 17 października 1942, w stosunku do treści uchwalonej 8 października było uwzględnienie w art. 12 dodatkowo kompetencji Ministra Spraw Zagranicznych ,ze względu na konieczność uzgodnienia postępowania z innymi państwami alianckimi co do wydania i wykonania dekretu" ${ }^{164}$. Jak podkreślał Komarnicki, przed ogłoszeniem dekretu konieczne było porozumienie się z rządami państw alianckich. Rosnące w drugiej połowie 1942 roku uznanie dla koncepcji represji karnej zbrodniarzy wojennych, wyrażone w przemówieniach Franklina D. Roosevelta i Winstona Churchilla z sierpnia i września 1942 roku, podczas zebrania Inter-Allied Commission on the Punishment of War Crimes 20 sierpnia 1942 roku oraz przez lorda kanclerza Simona podczas wystąpienia w Izbie Lordów 7 października 1942 roku, minister sprawiedliwości wiązał w pewnej mierze ze staraniami rządu polskiego na arenie międzynarodowej w tej dziedzinie i zaznaczał, że ogłoszenie przygotowanej ustawy dawało rządowi polskiemu możliwość dalszego wywierania wpływu na stanowisko aliantów i kształtowanie go w myśl polskich postulatów. Szczególne znaczenie Wacław Komarnicki przypisywał wypowiedzi lorda Fredericka Maughama na forum London International Assembly 28 września 1942 roku, w którym wskazywał, że „retroaktywność ustaw bynajmniej nie jest obca prawu angielskiemu" oraz przekonywał, że w wypadku ustaw specjalnych dotyczących karania zbrodniarzy wojennych nie da się jej uniknąc ${ }^{165}$. Sytuacja międzynarodowa w opinii ministra sprawiedliwości niewątpliwie sprzyjała ogłoszeniu dekretu, nasilenie zaś terroru w Polsce i konieczność przeciwdziałania niemieckiej polityce eksterminacyjnej nie pozwalały dalej zwlekać z publikacją ustawy. Przedstawiona przez Komarnickiego argumentacja okazała się skuteczna. Dnia 17 października 1942 roku projekt dekretu Prezydenta RP o odpowiedzialności karnej za zbrodnie wojenne został przyjęty przez Radę Ministrów, a uchwałą z 3 listopada tego roku przekazany do zaopiniowania Radzie Narodowej RP ${ }^{166}$.

164 IPMS, PRM-K. 102/51c, k. 22-27, Protokoly..., t. 5, s. 38-51.

165 Komarnicki zwracał przy tym uwagę, że ,powściągliwe stanowisko rządu brytyjskiego odnośnie tego zagadnienia wypływa z innych [niż prawnicze - D.U.] motywów: czysto politycznych, odnoszących się do brytyjskich celów wojny i do taktyki dyplomatycznej w tej dziedzinie" - Referat Ministra Sprawiedliwości o projekcie dekretu o odpowiedzialności karnej za zbrodnie wojenne, wygłoszony na posiedzeniu Rady Ministrów dnia 17 października 1942 roku, IPMS, PRM-K. 102/51 c, k. 28-31, Protokoty..., t. 5, s. 42-47, tu: s. 45.

166 Zob. Protokół posiedzenia Rady Ministrów w dniu 3 listopada 1942 roku, IPMS, PRM-K. 102/52a, k. 2-6, Protokoty..., t. 5, s. 52-56, tu: s. 56. 


\section{Obrady Komisji Prawno-Politycznej Rady Narodowej RP i redakcja ostatecznego tekstu dekretu}

Ostatni etap prac nad tekstem dekretu Prezydenta RP o odpowiedzialności karnej za zbrodnie wojenne przypada na pierwsze tygodnie 1943 roku. W dniach 7 grudnia 1942 i 5 stycznia 1943 roku odbyły się posiedzenia Komisji Prawno-Politycznej Rady Narodowej RP poświęcone zmianom w projekcie dekretu ${ }^{167}$. Podobnie jak na wcześniejszych etapach pracy nad tekstem, zaproponowane przez Radę Narodową zmiany dotyczyły art. 1, w którym sugerowano rozszerzenie zakresu osób objętych dekretem przez zastąpienie sformułowania „osoby [...] pozostające w służbie Rzeszy Niemieckiej bądź tych państw” słowami: „osoby działające na rzecz Rzeszy Niemieckiej lub państw z nią sprzymierzonych lub związanych”. Chodziło o odpowiedzialność karną osób, „które formalnie nie pozostają w służbie Rzeszy Niemieckiej, jednakże działają na jej rzecz i oddają usługi w zakresie objętym postanowieniami dekretu"168. W art. 3 proponowano niewprowadzanie ograniczeń dotyczących czasu trwania ograniczenia wolności (w poprzedniej wersji projektu było to $14 \mathrm{dni}$ ) oraz uwzględnienie jako dodatkowej formy kwalifikowanej przestępstwa określonego w art. 2 dekretu zmuszenia do ,poddania się czynowi nierządnemu lub przymusowemu zapłodnieniu”, przez co w sposób szczególny zwrócono uwagę na przestępstwa seksualne i przemoc uwarunkowaną płcią ${ }^{169}$, stanowiące istotny element eksterminacyjnej polityki okupanta. Kolejnym uzupełnieniem tekstu dekretu było dodanie nowego artykułu (art. 9) w brzmieniu: „Kto działaniem lub zaniechaniem pomaga osobom winnym przestępstw objętych niniejszym dekretem do uchylenia się od odpowiedzialności, podlega karze więzienia, więzienia dożywotniego lub karze śmierci" ${ }^{170}$. Przedmiotem dyskusji Komisji Prawno-Politycznej Rady Narodowej był także problem właściwości sądów - powszechnych czy wojskowych - i trybu postępowania w sprawach o przestępstwa objęte dekretem prezydenckim. Dotychczasowy art. 11 ustanawiający właściwość sądów wojskowych, orzekających w trybie postępowania wojennego, sugerowano zastąpić następującą regulacją: „Postępowanie sądowe w sprawach o przestępstwa objęte niniejszym dekretem zostanie określone osobnym dekretem" "171. W związku z tym kompetencję wykonania przepisów dekretu, zarezerwowaną dotychczas w art. 12 dla Ministra Sprawiedliwości, Ministra Spraw Wojskowych i Ministra Spraw Zagranicznych, postanowiono powierzyć wyłącznie Ministrowi Sprawiedliwości. Projekt dekretu o odpowiedzialności karnej za zbrodnie wojenne wraz ze zmianami zaproponowanymi przez Komisję

167 AAN 2/133/0/44, k. 348-350.

168 Ibidem, k. 348.

169 Zob. D. Plesch, Human Rights after Hitler: The Lost History of Prosecuting Axis War Crimes, Georgetown 2017, s. 13-18.

170 AAN 2/133/0/44, k. 349.

171 Ibidem, k. 349. 
Prawno-Polityczną zaopiniowane zostały pozytywnie przez Radę Narodową RP podczas posiedzenia 8 lutego 1943 roku, a 13 lutego przesłane przez Przewodniczącego Rady Narodowej, Stanisława Grabskiego, premierowi Sikorskiemu oraz ministrom Mikołajczykowi i Komarnickiemu.

Wniosek na Radę Ministrów o przyjęcie tekstu „Dekretu Prezydenta RP o odpowiedzialności karnej za zbrodnie wojenne” Wacław Komarnicki złożył 1 marca 1943 roku, załączając do niego ostateczną wersję ustawy specjalnej, opracowaną przy uwzględnieniu większości poprawek Rady Narodowej podczas Posiedzenia Sekcji VI Techniki Ustawodawczej Komisji Prac Ustawodawczych 18 lutego 1943 roku $^{172}$. Artykuł 1 ustanawiał odpowiedzialność karną osób „przynależnych do Rzeszy Niemieckiej lub państw z nią sprzymierzonych lub współdziałających, jako też innych osób działających w interesie Rzeszy Niemieckiej lub rzeczonych państw, za przestępstwa popełnione po dniu 31 sierpnia 1939 roku bez względu na miejsce popełnienia czynu”173. Artykuł 2 stanowił: „Kto wbrew normom prawa międzynarodowego dopuszcza się czynu na szkodę Państwa Polskiego, polskiej osoby prawnej lub obywatela polskiego, podlega karze więzienia"174. W myśl art. $3 \mathrm{w}$ wypadkach, gdy czyn ten spowodował śmierć, szczególne udręczenie, kalectwo, trwałą chorobę fizyczną lub psychiczną, trwałą niezdolność do pracy zawodowej, poddanie czynowi nierządnemu lub wysiedlenie obywatela polskiego, sprawca podlegał karze dożywotniego więzienia lub karze śmierci.

Zaostrzony wymiar kary przewidziany został także w kolejnych paragrafach, w sytuacji gdy czyn wymieniony w art. 2 sprowadził w Polsce niebezpieczeństwo powszechne dla życia lub zdrowia ludzkiego (art. 4) lub wobec osób zmuszających obywateli polskich do wstąpienia do wojska obcego lub do pracy dla nieprzyjaciela, niezgodnej z normami prawa międzynarodowego (art. 5). Artykuł 6 stanowił: „1) kto orzekając w imieniu władz okupacyjnych na podstawie przepisów prawnych, wydanych wbrew normom prawa międzynarodowego, wyrządza krzywdę obywatelowi polskiemu, podlega karze więzienia. 2) Jeśli tego rodzaju orzeczenie spowodowało jeden ze skutków wymienionych w art. 3., sprawca podlega karze więzienia dożywotnio lub karze śmierci”175. Artykuł 7 wprowadzał karę dożywotniego pozbawienia wolności lub karę śmierci w wypadkach rabunku, kradzieży, zniszczenia lub istotnego uszkodzenia mienia publicznego lub prywatnego, jeżeli mienie to miało wartość ogólnonarodową. Artykuł 8 przewidywał możliwość orzeczenia wobec skazanego kar dodatkowych przepadku majątku i utraty zdolności do dziedziczenia. Zgodnie z art. 9 kara dożywotniego więzienia lub kara śmierci groziła za udzielenie pomocy ,sprawcy przestępstwa objętego dekretem niniejszym do uchylenia się od odpowiedzialności"176 lub za

172 Ibidem, k. 359.

173 Ibidem.

174 Ibidem.

175 Ibidem.

176 Ibidem. 
niezapobieżenie ucieczce czy innej formie uchylenia się od odpowiedzialności karnej sprawcy, jeśli było to możliwe. Artykuł 10 ustanawiał odpowiedzialność karną osoby zarówno wydającej, jak i wykonującej rozkaz popełnienia przestępstwa określonego w dekrecie. Artykuł 11 stanowił, iż bieg terminów przedawnienia, przewidziany w art. 86 kodeksu karnego w sprawach o zbrodnie wojenne, rozpoczyna się z upływem sześciu miesięcy od wznowienia czynności Sądu Najwyższego. W art. 12 wykonanie dekretu zostało powierzone Ministrowi Sprawiedliwości, a ostatni, art. 13 stanowił, iż dekret wchodzi w życie z dniem ogłoszenia.

W tym brzmieniu projekt został przedstawiony przez ministra sprawiedliwości i uchwalony przez Radę Ministrów podczas posiedzenia plenarnego 22 marca 1943 roku $^{177}$. Podpisany przez prezydenta Władysława Raczkiewicza 30 marca Dekret Prezydenta RP o odpowiedzialności karnej za zbrodnie wojenne został ogłoszony w Dzienniku Ustaw 31 marca 1943 roku.

\section{$* * *$}

Pomimo znacznego czasu dzielącego opracowanie pierwszego projektu dekretu w maju 1942 roku i moment ogłoszenia tego aktu prawnego 31 marca 1943 roku dekret Prezydenta RP o odpowiedzialności karnej za zbrodnie wojenne był pierwszym aktem prawa wewnętrznego regulującym kwestię karania zbrodniarzy wojennych, opracowanym i ogłoszonym w latach II wojny światowej przez rząd jednego z państw alianckich ${ }^{178}$. Zarówno jako pierwsza próba określenia nieregulowanych dotąd ani przez prawo międzynarodowe, ani przez ustawy krajowe zasad pociągania do indywidualnej odpowiedzialności karnej winnych naruszeń praw i zwyczajów prowadzenia wojny, jak i jako element szeroko zakrojonej, zapoczątkowanej jesienią 1939 roku polityki polskich władz emigracyjnych ścigania i karania zbrodniarzy wojennych Dekret Prezydenta RP o odpowiedzialności karnej za zbrodnie wojenne z 30 marca 1943 roku stanowi istotny punkt odniesienia badań nad historią rozliczeń zbrodni nazistowskich oraz badań z zakresu rozwoju prawa karnego międzynarodowego przed rokiem 1945. Jak już nadmieniono, polskie starania o zdobycie poparcia aliantów wobec postulatu represji karnej zbrodniarzy wojennych rozpoczęły się na przełomie lat 1939/1940 i obejmowały sporządzanie dokumentacji zbrodni niemieckich, akcję informacyjno-dyplomatyczną o okrucieństwach popełnianych w Polsce i innych krajach okupowanych

177 Protokół posiedzenia Rady Ministrów z dnia 22 marca 1943 rok $u$, IPMS, PRM-K.102/56e, k. 18-21, Protokoty ..., t. 5, s. 315-318, tu: s. 315.

178 Dnia 19 kwietnia 1943 roku został ogłoszony Dekret Prezydium Rady Najwyższej ZSRR, określający zasady karania nazistowskich zbrodniarzy wojennych, zob. F. Ryszka, Norymberga. Prehistoria i ciag dalszy, Warszawa 1982, s. 114. W sierpniu 1943 roku ustawy specjalne w tym zakresie ogłosiły także Holandia i Czechosłowacja - United Nations War Crimes Commission, History of the..., s. 84 . 
oraz deklaracje międzynarodowe potępiające te zbrodnie, w tym deklarację z St. James's, w której przedstawiciele rządów emigracyjnych zapowiedzieli postawienie zbrodniarzy przed sądem. Opracowanie aktu prawa wewnętrznego, określającego zasady karania za zbrodnie wojenne, traktowane było przez znaczną część polskich prawników jako naturalna kontynuacja wcześniejszych inicjatyw na rzecz popularyzacji na arenie międzynarodowej idei sankcji karnej za przestępstwa wojenne oraz jako konieczna odpowiedź na oczekiwania społeczeństwa polskiego domagającego się ,ukarania sprawców niebywałych zbrodni, powodujących wielkie cierpienie ludności naszego kraju"179. Oba wspomniane czynniki: zachowawcze stanowisko państw alianckich, przede wszystkim Wielkiej Brytanii i Stanów Zjednoczonych, okazujących rezerwę zarówno wobec dostarczanych przez rząd polski informacji o dokonywanych na terenach okupowanych zbrodniach, jak i wobec postulatu określenia zasad odpowiedzialności karnej przestępców wojennych oraz kierowane pod adresem gabinetu gen. Sikorskiego apele z kraju o podjęcie zdecydowanych kroków na rzecz „natychmiastowego ukarania [niemieckiego - D.U.] barbarzyństwa" i utworzenia międzynarodowego trybunału karnego w celu osądzenia wszystkich zbrodni popełnionych przez Niemców ${ }^{180}$ okazały się kluczowe dla przebiegu prac nad tekstem dekretu Prezydenta RP o odpowiedzialności karnej za zbrodnie wojenne. Napięcia i spory, jakie towarzyszyły tym pracom przez cały okres ich trwania, w znacznej mierze wynikały z niemożności sprostania oczekiwaniom każdej ze stron i znalezienia „złotego środka” pomiędzy koniecznością przeciwdziałania niemieckiemu terrorowi i nasilającym się aktom eksterminacji ludności ziem okupowanych oraz obawami o reakcję wielkich mocarstw na samodzielne działania władz polskich w tej dziedzinie i możliwe osłabienie pozycji międzynarodowej rządu polskiego w wyjątkowo trudnym momencie pogarszających się relacji z ZSRR. Mając na uwadze okoliczności powstania dekretu Prezydenta RP o odpowiedzialności karnej za zbrodnie wojenne, ogłoszenie tej ustawy specjalnej, pomimo dość ogólnego charakteru zawartych $\mathrm{w}$ niej regulacji ${ }^{181}$, należy uznać za wielkie osiągnięcie

179 Uzasadnienie z 23 czerwca 1942 roku, AAN 2/133/0/6/44, k. 395.

180 Raport delegata rządu z 12 czerwca 1942 roku, IPMS, A9III/2b/9, strony niepaginowane.

181 Z taką oceną spotkał się dekret Prezydenta RP o odpowiedzialności karnej za zbrodnie wojenne w Departamencie Sprawiedliwości Delegatury Rządu na Kraj. Por. Uwagi do dekretu londyńskiego o ściganiu przestępstw wojennych, AAN 2/133/0/6/83, k. 29-35: „Po zaznajomieniu się z treścią tego dekretu Departament poczuwa się do obowiązku przedstawienia swoich rozważań i wniosków co do konieczności bądź poczynania znacznych zmian i uzupełnień w dekrecie z 20 marca 1943 roku bądź zastąpienia tego dekretu nowym, dekret bowiem, w obecnym brzmieniu, nie spełni, zdaniem Departamentu, swego zadania, mianowicie przykładnego ukarania zbrodniarzy i ich wspólników oraz popleczników, dania zadośćuczynienia poczuciu sprawiedliwości i uspokojenia poruszonego i oburzonego w najwyższym stopniu sumienia Narodu, gdyż dotknie tylko niewielu przestępców i tylko malej liczby przestępstw, a ponad to ma jeszcze inne braki, powstałe prawdopodobnie wskutek tego, że władze ustawodawcze na obczyźnie nie miały dokładnego obrazu tego, co dzieje się w Kraju...”. W Departamencie Sprawiedliwości opracowany został projekt dekretu o karaniu niektórych przestępstw popełnionych w czasie najazdu wroga, w sposób dużo bardziej 
Rządu RP na uchodźstwie. Trwająca rok debata rządowa nad tekstem dekretu i jego ogłoszenie w marcu 1943 roku wyznaczają nie tylko ważną cezurę w polityce polskich władz emigracyjnych wobec problemu represji karnej zbrodniarzy wojennych, lecz także w szerzej pojmowanym procesie kształtowania się koncepcji ścigania i karania zbrodniarzy wojennych w latach II wojny światowej, w który zaangażowane były zarówno rządy europejskich państw okupowanych, wielkie mocarstwa, jak i międzynarodowe stowarzyszenia prawnicze: London International Assembly czy Cambgridge Commisson. Przykład prac rządu polskiego w omawianej dziedzinie dowodzi, że proces ten charakteryzowały „dwie dynamiki" oraz że rozpoczął się on na długo przed utworzeniem Komisji Narodów Zjednoczonych ds. Spraw Zbrodni Wojennych jesienią 1943 roku, podpisaniem deklaracji moskiewskiej 30 października 1943 roku czy opracowaniem Karty Międzynarodowego Trybunału Wojskowego załączonej do Porozumienia międzynarodowego w przedmiocie ścigania i karania głównych przestępców wojennych Osi Europejskiej z 8 sierpnia 1945 roku.

\section{Bibliografia}

\section{Źródła prawa}

Deklaracja Rządu Jedności Narodowej z 24 lutego 1942 roku, Dz.U. RP z 1943 r. Nr 8.

Dekret Prezydenta RP o odpowiedzialności karnej za zbrodnie wojenne z dnia 30 marca 1943 roku, Dz.U. RP z 1943 r. Nr 3, poz. 6.

Dekret Prezydenta Rzeczypospolitej z dnia 29 września 1936 roku — Kodeks wojskowego postępowania karnego, Dz.U. z 1936 r. Nr 76, poz. 537.

Porozumienie międzynarodowe w przedmiocie ścigania i karania głównych przestępców wojennych Osi Europejskiej, do którego załączona została Karta Międzynarodowego Trybunału Wojskowego, Dz.U. z 1947 r. Nr 63, poz. 367.

Rozporządzenie Prezydenta Rzeczypospolitej z dnia 11 lipca 1932 roku - Kodeks karny, Dz.U 1932 r. Nr 60, poz. 571.

Rozporządzenie Prezydenta Rzeczypospolitej z dnia 21 października 1932 roku — Kodeks karny wojskowy, Dz.U. z 1936 r. Nr 91, poz. 765.

Rozporządzenie Prezydenta Rzeczypospolitej z dnia 24 października 1934 roku o niektórych przestępstwach przeciwko bezpieczeństwu państwa, Dz.U. z 1934 r. Nr 94, poz. 851.

Rozporządzenie Rady Ministrów z dnia 1 września 1939 roku o wprowadzeniu postępowania doraźnego przed sądami powszechnymi w sprawach o niektóre przestępstwa, Dz.U. z 1939 r. $\mathrm{Nr} 87$, poz. 554.

Traktat pokoju między mocarstwami sprzymierzonemi i skojarzonemi i Niemcami, podpisany w Wersalu dnia 28 czerwca 1919 roku, Dz.U. z 1920 r. Nr 35, poz. 200.

Zarządzenie Prezydenta Rzeczypospolitej z dnia 1 września 1939 roku o stanie wojennym, Dz.U. z 1939 r. Nr 86, poz. 544.

precyzyjny regulujący zasady odpowiedzialności karnej za zbrodnie wojenne. Na ten temat zobacz także F. Ryszka, Norymberga. Prehistoria..., s. 130-135. 


\section{Wydawnictwa zwarte}

Cybichowski Z., Prawo międzynarodowe publiczne i prywatne, Warszawa 1928.

Cyprian T., Sawicki J., Prawo Norymberskie. Bilans i perspektywy, Warszawa 1948.

Documents Relating to the Administration of Occupied Countries in Eastern Europe, New York 1941.

Hankel G., Die Leipziger Prozesse. Deutsche Kriegsverbrechen und ihre strafrechtliche Verfolgung nach dem Ersten Weltkrieg, Hamburg 2003.

Hułas M., Goście czy intruzi? Rząd polski na uchodźstwie wrzesień 1939-lipiec 1943, Warszawa 1996.

Jankiewicz A., W poszukiwaniu idei państwa prawa. Koncepcje Komisji Prac Ustawodawczych Rząu RP (1942-45), Warszawa 1992.

Kochavi A.J., Prelude to Nuremberg: Allied War Crimes Policy and the Question of Punishment of War Criminals, Chapel Hill-London 1998.

Kwiatkowski M., Rząd i Rada Narodowa RP w świetle faktów i dokumentów od września 1939 do lutego 1942, Londyn 1942.

Lachs M., The Ghetto of Warsaw, London 1942.

Makarewicz J., Kodeks karny z komentarzem, wyd. 5, Lwów 1938.

Ministerstwo Spraw Zagranicznych, L'Occupation Allemande et Sovietique de la Pologne, 1941.

Plesch D., Human Rights after Hitler: The Lost History of Prosecuting Axis War Crimes, Georgetown 2017.

Polish Ministry of Information, The persecution of Jews in German-occupied Poland, Alliance Printers and Publishers, Chicago 1940.

Polish Ministry of Information, The German New Order in Poland, London 1942.

Protokoły posiedzeń Komitetu Ministrów dla Spraw Kraju. Część 1: 1939-1941, oprac. W. Grabowski, Warszawa 2008.

Protokoły posiedzeń Rady Ministrów Rzeczypospolitej Polskiej, red. M. Zagórniak, t. 1-8, Kraków 1994-2008.

Punishment for War Crimes. The Inter-Allied Declaration Signed at St. James's Palace London on 13th January 1942 and Realtive Documents, document issued by the Inter-Allied Information Centre, London 1942.

Ryszka F., Norymberga. Prehistoria i ciag dalszy, Warszawa 1982.

Rząd Rzeczypospolitej Polskiej na Uchodźstwie, Ministerstwo Spraw Zagranicznych, The Polish White Book: Official Documents concerning Polish-German and Polish-Soviet Relations 1933-1939, London-Melbourne 1940.

Sprawa polska w czasie drugiej wojny światowej na arenie międzynarodowej. Zbiór dokumentów, oprac. S. Stanisławska, Warszawa 1965.

Stola D., Nadzieja i Zagłada. Ignacy Schwarzbart —żydowski przedstawiciel w Radzie Narodowej $R P$ (1939-1945), Warszawa 1995.

United Nations War Crimes Commission, History of the United Nations War Crimes Commission and the Development of the Laws of War, London 1948.

Willis J., Prologue to Nuremberg: The Politics and Diplomacy of Punishing War Criminals of the First World War, Westport 1982.

Winiarski B., Bezpieczeństwo, arbitraż, rozbrojenie, Poznań 1928.

Wrzyszcz A., Okupacyjne sadownictwo niemieckie w Generalnym Gubernatorstwie. 1939-1945. Organizacja i funkcjonowanie, Lublin 2008.

Studia nad Autorytaryzmem i Totalitaryzmem 41, nr 2, 2019

(C) for this edition by CNS 


\title{
Rozdział pracy zbiorowej
}

Uczkiewicz D., Verfolgung außerhalb der Heimat. Die Politik der polnischen Exilregierung bei der strafrechtlichen Verfolgung von NS-Kriegsverbrechen, [w:] Im Schatten von Nürnberg. Transnationale Ahndung von NS-Verbrechen, red. E. Heitzer, G. Morsch, R. Traba, K. Woniak, Metropol, Berlin 2018.

\section{Artykuły z czasopism}

Basak A., Kwestia ukarania zbrodni niemieckich na łamach „Biuletynu Informacyjnego” Armii Krajowej 1940-1945, „Acta Universitatis Wratislaviensis No 543. Historia” 36, 1981, s. 59-84.

Glaser S., Nullum crimen sine lege, ,Journal of Comparative Legislation and International Law” 24, nr 1, s. 29-37.

Kochavi A.J., The British Foreign Office versus the United Nations War Crimes Commission during the Second World War, „Holocaust \& Genocide Studies” 28, 1994, s. 28-49.

Kobierska-Motas E., Rząd polski na emigracji wobec problemu dokumentowania niemieckich przestęstw wojennych, „Pamięć i Sprawiedliwość” 38, 1995, s. 175-202.

Ryszka F., U progu Norymbergi. Ściganie zbrodni wojennych w projektach polskich władz emigracyjnych, „Czasopismo Prawno-Historyczne” 30, 1978, nr 2, s. 155-186.

\section{Zespoły archiwalne}

AAN 2/133/0/6/29, Archiwum Akt Nowych, Ministerstwo Sprawiedliwości Rządu RP [emigracyjnego] w Londynie, Komisja Prac Ustawodawczych, Plenum w dniach 2, 9 maja, 2, 3 , 8 czerwca $1942 \mathrm{r}$.

AAN 2/133/0/6/44, Archiwum Akt Nowych, Ministerstwo Sprawiedliwości Rządu RP [emigracyjnego] w Londynie, Komisja Prac Ustawodawczych, Sekcja V Prawa i Postępowania Karnego i Więziennictwa.

AAN 2/133/0/6/45, Archiwum Akt Nowych, Ministerstwo Sprawiedliwości Rządu RP [emigracyjnego] w Londynie, Komisja Prac Ustawodawczych, Sekcja VI Techniki Ustawodawczej, Protokoły Sekcji dotyczące projektów ustaw o karaniu za niektóre zbrodnie dokonane w czasie wojny.

AAN 2/133/0/6/69, Archiwum Akt Nowych. Ministerstwo Sprawiedliwości Rządu RP [emigracyjnego] w Londynie, Komisja Prac Ustawodawczych, I i II Konferencja Międzyministerialna w sprawie odpowiedzialności Niemców za przestępstwa popełnione przez nich na ziemiach okupowanych.

IPMS, A.10.3/3, Archiwum Instytutu Polskiego i Muzeum gen. Sikorskiego w Londynie, Ministerstwo Informacji i Dokumentacji, Dział Kontynentalny, Protokoły zebrań międzyalianckich i tekst deklaracji 9 krajów okupowanych.

IPMS, A.5.1/2, Archiwum Instytutu Polskiego i Muzeum gen. Sikorskiego w Londynie, Rada Narodowa RP, Protokoły posiedzeń 1942-1943.

IPMS, Kol. 180/30, Archiwum Instytutu Polskiego i Muzeum gen. Sikorskiego w Londynie, Kolekcja Stanisława Strońskiego, Informacje, raporty.

\author{
DECREE OF THE PRESIDENT OF THE POLISH REPUBLIC \\ ON CRIMINAL LIABILITY FOR WAR CRIMES OF 30 MARCH 1943
}

Studia nad Autorytaryzmem i Totalitaryzmem 41, nr 2, 2019

(C) for this edition by CNS 


\section{Summary}

On 30 March 1943 the Decree of the President of the Polish Republic on Criminal Liability for War Crimes, the first normative act setting down the legal basis for persecution of war criminals issued by one of the Allies during the Second World War, was proclaimed. The promulgation of the decree can be considered as the turning point in the Polish government-in-exile's policy towards the problem of the prosecution and punishment of Nazi criminals, which started in autumn 1939. After the announcement of the draft decree, developed by the Polish minister of justice, professor of state law, Wacław Komarnicki and by an international lawyer, professor of criminal law, Stefan Glaser in the spring of 1942, a fierce discussion on the legal act's concept broke out in the Polish government and lasted until November 1942. Although all Polish politicians agreed on the need to define the principles of individual criminal liability for war crimes, the proposal to promulgate criminal legislation with retroactive effect aroused much controversy. However, as the course of these debates shows, the critical point was not the mere fact of violating the lex retro non agit principle. The scepticism of some Polish politicians towards this idea resulted from purely pragmatic reasons and was caused by lack of support from the American and British governments for the proposal to define legal frames for the future trials of war criminals (this attitude changed only in spring 1945). This article presents the genesis and provisions of the Decree of the President of the Polish Republic on Criminal Liability for War Crimes of 30 March 1943 in the context of international debates on international criminal law and individual liability for war crimes. It argues that the legislative works on the decree and its proclamation in March 1943 mark an important point in the process of shaping the concept of prosecution and punishment of war criminals during the Second World War.

Keywords: war crimes, Second World War, Polish government in exile, individual liability for war crimes, Wacław Komarnicki.

Dominika Uczkiewicz

dominika.uczkiewicz@gmail.com 